\title{
High Mobility Group Box-1 and Blood-Brain Barrier Disruption
}

\author{
Masahiro Nishibori *, Dengli Wang, Daiki Ousaka and Hidenori Wake \\ Department of Pharmacology, Okayama University Graduate School of Medicine, Dentistry and Pharmaceutical \\ Sciences, Okayama 700-8558, Japan; wangdengli.cool@163.com (D.W.); daiki_ouou@hotmail.co.jp (D.O.); \\ wake-h@cc.okayama-u.ac.jp (H.W.) \\ * Correspondence: mbori@md.okayama-u.ac.jp
}

Received: 11 November 2020; Accepted: 8 December 2020; Published: 10 December 2020

\begin{abstract}
Increasing evidence suggests that inflammatory responses are involved in the progression of brain injuries induced by a diverse range of insults, including ischemia, hemorrhage, trauma, epilepsy, and degenerative diseases. During the processes of inflammation, disruption of the blood-brain barrier (BBB) may play a critical role in the enhancement of inflammatory responses and may initiate brain damage because the BBB constitutes an interface between the brain parenchyma and the bloodstream containing blood cells and plasma. The BBB has a distinct structure compared with those in peripheral tissues: it is composed of vascular endothelial cells with tight junctions, numerous pericytes surrounding endothelial cells, astrocytic endfeet, and a basement membrane structure. Under physiological conditions, the BBB should function as an important element in the neurovascular unit (NVU). High mobility group box-1 (HMGB1), a nonhistone nuclear protein, is ubiquitously expressed in almost all kinds of cells. HMGB1 plays important roles in the maintenance of chromatin structure, the regulation of transcription activity, and DNA repair in nuclei. On the other hand, HMGB1 is considered to be a representative damage-associated molecular pattern (DAMP) because it is translocated and released extracellularly from different types of brain cells, including neurons and glia, contributing to the pathophysiology of many diseases in the central nervous system (CNS). The regulation of HMGB1 release or the neutralization of extracellular HMGB1 produces beneficial effects on brain injuries induced by ischemia, hemorrhage, trauma, epilepsy, and Alzheimer's amyloidpathy in animal models and is associated with improvement of the neurological symptoms. In the present review, we focus on the dynamics of HMGB1 translocation in different disease conditions in the CNS and discuss the functional roles of extracellular HMGB1 in BBB disruption and brain inflammation. There might be common as well as distinct inflammatory processes for each CNS disease. This review will provide novel insights toward an improved understanding of a common pathophysiological process of CNS diseases, namely, BBB disruption mediated by HMGB1. It is proposed that HMGB1 might be an excellent target for the treatment of CNS diseases with BBB disruption.
\end{abstract}

Keywords: high mobility group box-1; blood-brain barrier; inflammation; stroke; trauma; vascular endothelial cell; pericyte; monoclonal antibody

\section{Introduction}

The brain receives $15 \%$ of blood flow from cardiac output and consumes $20 \%$ of the total supply of oxygen from blood, although the wet weight of the brain is only $2 \%$ of body weight. Blood flow and oxygen consumption in the brain are the highest among the organs because brain tissue uses most of its energy to continuously maintain the intra/extracellular ion environment through ATP-dependent ion transport, especially in neurons [1]. This feature allows the brain to maintain the integrity and 
activity of the neural network. Cerebral blood flow (CBF), oxygen delivery, and energy metabolite supply should be coordinated with neural activity by integrating the demands from neuronal and glial elements. A recent study on the physiological and pathophysiological processes involved in the control of brain functions and relevant disorders introduced the concept of the "neurovascular unit" (NVU) to help model the intimate relationship between the neural and vascular systems [1-3].

The blood-brain barrier (BBB) is a distinctive structure of capillary vessels in the brain [4-6]. The BBB, which is composed of vascular endothelial cells, pericytes, extracellular matrix, and endfeet of astrocytic processes, functions as a barrier against the entry of microorganisms, toxins, bioactive substances, and many kinds of solutes, including drugs (Figure 1) $[2,3,6,7]$. The BBB also limits the improvident infiltration of white blood cells into the brain parenchyma. On the other hand, transporter systems exist in each component of the BBB to transport a diverse range of substances that are necessary for the maintenance of brain function [3,8-10]. It is well known that the capillaries in the brain have higher numbers of pericytes compared with the capillaries in peripheral vasculatures [7], and pericytes may play an important role in maintaining the integrity of the BBB, the contractility of capillaries, and the development and maturation of this structure [3,11-13].

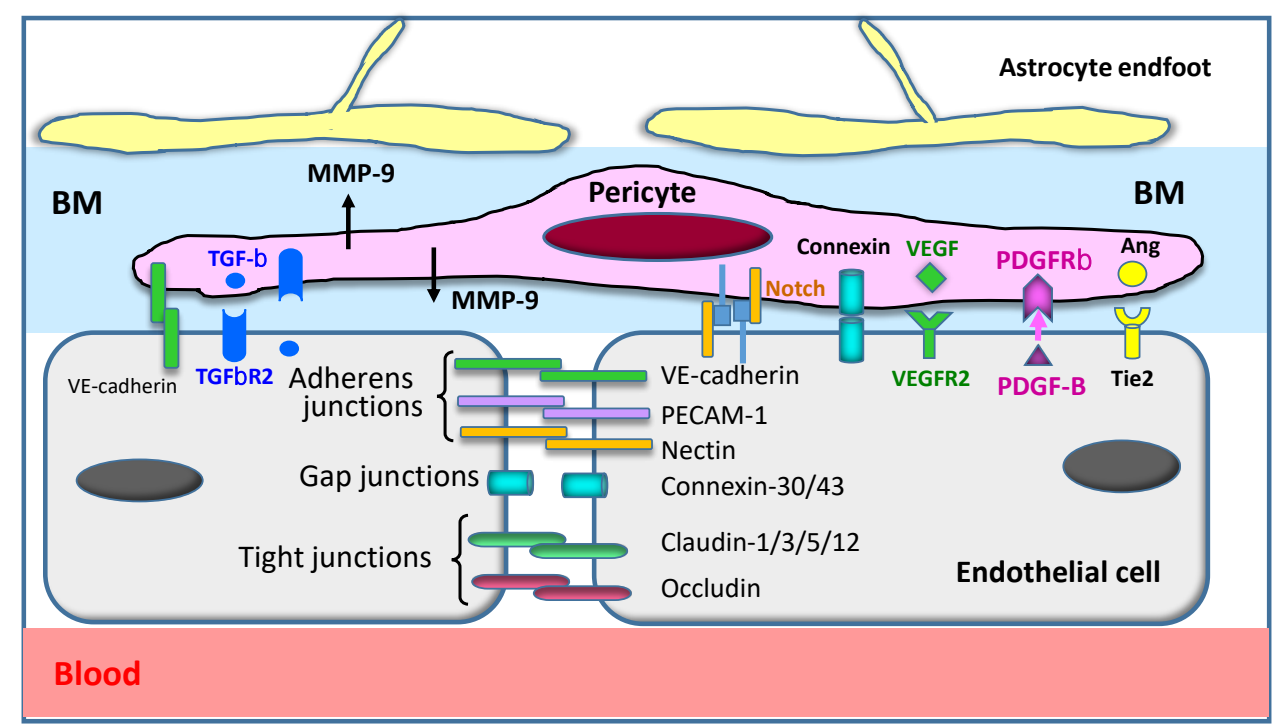

Figure 1. Structure of the blood-brain barrier (BBB). The BBB consists of vascular endothelial cells, pericytes, a basement membrane (BM), and astrocyte endfeet. Cellular components are integrated with many adhesive molecules and are functionally regulated by ligand-receptor systems. The major factors are drawn in this figure. Ang: angiopoietin; BM: basement membrane; MMP-9: matrix metallo proteinase-9; PECAM-1: platelet endothelial cell adhesion molecule-1; PDGF-B: platelet-derived growth factor-B; PDGFRb: platelet-derived growth factor receptor beta; TGF-b: transforming growth factor-b; TGFbR2: Transforming growth factor-b receptor 2; VE-cadherin: vascular endothelial cadherin; VEGF: vascular endothelial growth factor; VEGFR2: vascular endothelial growth factor receptor 2.

Recent studies have demonstrated that dysfunction or disruption of the BBB may be involved in many diseases, including brain infarction [14,15], hemorrhage [3,16], trauma [17-19], and epilepsy [20-23], as well as neurodegenerative diseases $[3,24,25]$. Disruption of the BBB appears to be intimately associated with brain inflammatory responses $[1,3,25]$, and the infiltration of immune cells through the dysregulated BBB [26] may enhance the inflammation inside the brain parenchyma in collaboration with the activated residual glial cells $[5,27,28]$. Thus, the BBB functions as the interface between circulating inflammatory and immune cells and brain parenchymal cells, and, therefore, functional regulation and maintenance of the BBB are very important for strictly controlling the maintenance and protection of brain physiology [27]. 
High mobility group box-1 (HMGB1) is a highly conserved nonhistone nuclear protein that contributes to the architecture of chromatin DNA and regulates the transcriptional activity of genes. A neurite-promoting factor, amphoterin, purified from perinatal rat brain $[29,30]$, was found to be identical to HMGB1 [30,31]. HMGB1 was also reported to be a late mediator of endotoxemia in mice [32] and has been shown to function as a representative damage-associated molecular pattern (DAMP), promoting inflammatory responses in many disease conditions [25,33-35]. In an earlier study, HMGB1 was reported to be released from necrotic cells [36], but soon thereafter, it was recognized that HMGB1 may be released from living cells as well under different stress conditions, including hypoxia, ischemia, and stimulation by cytokines $[25,33,37]$. Therefore, HMGB1 appears to be a sensor molecule that responds to a diverse range of stimuli. Once released into extracellular space, HMGB1 stimulates multiple receptors, including RAGE and TLR-4/2 [33]. In addition, HMGB1 may bind to IL-1a, IL-1b, CXCL12, DNA, RNA, and LPS when these molecules coexist with HMGB1, leading to enhanced activation of the cognate receptors of each factor [37,38]. HMGB1 has also been reported to exhibit a chaperone-like function, by which it carries LPS and nucleic acids into cells [39,40]. This diverse range of functional modes may characterize HMGB1 as a proinflammatory molecule.

There is increasing evidence suggesting the involvement of BBB disruption in many kinds of brain diseases, including brain infarction, hemorrhage, trauma, epilepsy, and neurodegenerations $[3,24,25]$. BBB disruption significantly contributes to brain inflammation through the leakage of plasma factors into the brain, the blocking of endothelial-pericyte interaction, the activation of glial cells, and the induction of immune cell migration into brain tissue $[3,26,41]$. Conversely, brain inflammation facilitates BBB disruption through digestion of the basement membrane by proteinases and the activation of lesions of component cells [41-43]. These mutual events may lead to brain edema, hypoxia, excitatory amino acid release, and continued elevation of calcium in neurons, and eventually to neuronal death $[3,25]$.

In this review, we will focus on the breakdown and disruption of the BBB under different conditions, including brain infarction, brain hemorrhage, brain trauma, epilepsy, degenerative diseases, and systemic inflammation, and we will discuss the involvement of released HMGB1 in the processes. We propose that the direct neutralization of extracellular HMGB1 by a monoclonal antibody (mAb) or the inhibition of HMGB1 release by small molecules may be a novel strategy for the treatment of neuronal injuries induced by different insults.

Restriction of the penetration of a diverse range of substances into the brain is the fundamental function of the BBB $[3,4,6]$. The BBB is composed of vascular endothelial cells, pericytes, endfeet of astrocytes, and a basement membrane. We will briefly summarize the molecular components forming the tight junction and adherens junction between the vascular endothelial cells and the interaction between endothelial cells and other elements. Figure 1 provides a schematic view of vascular endothelial cells and the major molecules controlling cell shape, cytoskeleton, and mutual cell attachment. VE-cadherin is a homodimeric-binding molecule between endothelial cells that forms a tight border lining. Inside the endothelial cells, VE-cadherin is connected to the alpha/beta-catenin molecule, which, in turn, is linked to the main cytoskeletal element, F-actin. ZO-1 and occludins are the main members of adherens junctions. Brain and retinal vessels have much higher numbers of pericytes than the vessels of other organs [7]. Pericytes maintain the BBB structure, control the contractility of capillaries, and regulate the proliferation, differentiation, and maturation of the component cells-i.e., vascular endothelial cells and oligodendrocytes-through the production of growth factors such as PDGF-BB $[3,44,45]$. Thus, pericytes play very important roles inside the BBB, orchestrating many cells [46]. To maintain brain function, specific transporters for a diverse range of substances are present on both the luminal and abluminal sides of endothelial cells, pericytes, and astrocytes. Several excellent reviews have been published on this issue [3,47-49]. In Figure 1, the factors maintaining the integrity and restriction of BBB permeability are listed, except for MMP-9. HMGB1 is one of the factors inducing an increase in BBB permeability, in association with morphological changes in vascular endothelial cells and pericytes $[15,50]$. 


\section{Stroke and BBB Disruption}

Stroke, a condition associated with hypertension, atherosclerosis, and hyperlipidemia, is one of the leading causes of death worldwide. Stroke not only causes mortality in the acute phase but also induces severe neurological complications such as motor paralysis, impairment of higher cognitive functions, and postischemic epilepsy in survivors. However, few effective therapeutics are available for stroke. Stroke actually comprises three kinds of cerebrovascular diseases: brain infarction by thrombosis due to atherosclerosis and atrial fibrillation, hemorrhage by disruption of the vascular wall, and subarachnoid hemorrhage due to a rupture of aneurysm. Thus, the pathophysiological processes that are characteristic of each disease condition are expected to be different, and specific therapeutic strategies must be developed for each type of cerebrovascular disease included under the rubric of stroke.

Based on their experiments using a middle cerebral artery occlusion/reperfusion (MCAO)-induced injury model in rats, Kim et al. [51] first suggested the relationship between HMGB1 and brain inflammatory injury. They observed that microinjections of short hairpin RNA for HMGB1, which reduced the expression of HMGB1 in the transfected area, inhibited neuronal death after MCAO. They also found that the expression of inflammation-related molecules such as TNF-a, iNOS, IL-1b, and COX-2 was suppressed significantly. Since those factors are thought to originate from the microglia, Kim and colleagues suggested that microglia might be involved in the inflammatory responses mediated by HMGB1 in MCAO rats [51]. Several other groups performed experiments using similar MCAO animal models in rats or mice and found that the neurons in ischemic regions release HMGB1 [14,52-54]. HMGB1 translocation in neurons has been shown to occur at an early time point during the ischemic phase [15,52-54]. In fact, intranuclear translocation has been observed even $1 \mathrm{~h}$ after the start of ischemia [15]. This suggests that HMGB1 translocation is very quick and sensitive to hypoxia and a very early event among the responses after ischemia $[15,26]$ (Figure 2). Such early occurrences of HMGB1 translocation after ischemic insult have also been observed in neonatal rats [55]. In the MCAO model, BBB disruption was evident by electron microscopic observation and by leakage of albumin-binding dye. Using electron microscopy, Zhang et al. [15] showed that the swelling of astrocyte endfeet was remarkable at $3 \mathrm{~h}$ after the start of reperfusion around capillary vessels, and the endfeet membrane often detached from the basal membrane of capillary vessels (Figure 2). Dissociation of the tight junction between vascular endothelial cells has also been observed [15]. These are the typical features of BBB disruption under electron microscopy, and all of them were inhibited by the systemic administration of anti-HMGB1 mAb [15]. The morphological changes in BBB structures were consistent with the results of BBB permeability measurement and upregulation of aquaporin-4 on the astrocytic endfeet around capillaries after ischemia $[14,15]$, which were also suppressed by anti-HMGB1 mAb treatment.

Western blotting measurement of HMGB1 content in the core areas of brain ischemia revealed a dramatic decrease in HMGB1 in the core region, while immunohistochemical studies strongly suggested the release of HMGB1 from neurons in severely injured areas [14,15]. It was also reported that an increase in HMGB1 protein was observed in the area of the penumbra after ischemia or hemorrhage [53,56], suggesting that HMGB1 dynamics in such areas differ according to the extent of the neural lesion. Thus, it is likely that the dramatic decrease in HMGB1 was observed in areas with high levels of cell death in the acute phase, whereas the increase in HMGB1 may have been seen in the surviving areas, where the ischemic response included an increase of HMGB1 mRNA.

Zhang et al. [15] detected an increase in HMGB1 levels in both cerebrospinal fluid (CSF) and plasma of brain ischemic animal models. Similar increases in HMGB1 in CSF or plasma have been observed in stroke patients with brain infarction [57], hemorrhage [58], and subarachnoid hemorrhage [59,60]. These findings indicate that some portion of the HMGB1 released from the damaged brain tissue of patients gets into their CSF and plasma, and the degree of increase in HMGB1 probably reflects the severity of their disease states [58-60]. In fact, a good correlation between plasma HMGB1 levels and 
poor outcomes has been reported [61,62]. Therefore, the determination of plasma HMGB1 in patients in the acute phase appears to have prognostic value.

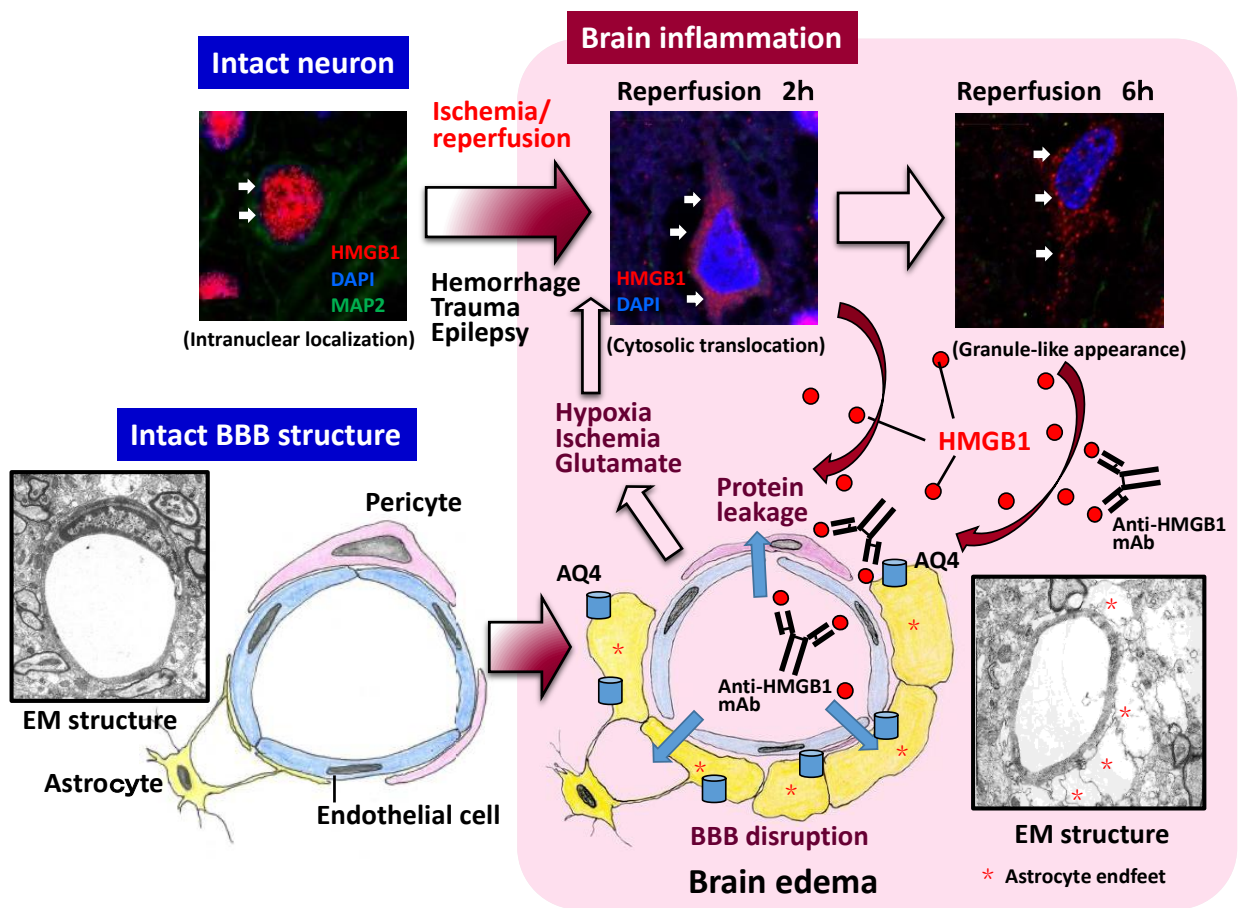

Figure 2. HMGB1 translocation and release after insults and its involvement in BBB disruption. In the upper three squares, typical HMGB1 translocation and release from the nucleus to extracellular space are shown after $2 \mathrm{~h}$ of occlusion/reperfusion of the middle cerebral artery. The released HMGB1 then affects the vascular endothelial cells and pericytes, leading to protein leakage and brain edema formation. BBB disruption further promotes HMGB1 translocation. There might be a positive feedback loop between BBB disruption and HMGB1 translocation. The existence of such a loop may be a reason why anti-HMGB1 therapy inhibited BBB disruption and HMGB1 translocation simultaneously. AQ4: aquaporin 4; BBB: blood-brain barrier; EM: electron microscopy; HMGB1: high mobility group box-1; $\mathrm{mAb}$ : monoclonal antibody.

Intravenous injection of anti-HMGB1 mAb significantly protected against BBB disruption induced by ischemia and hemorrhage in rats [14-16] while simultaneously inhibiting the expression of inflammation-related molecules and the activation of microglia. Using a reconstituted BBB in vitro, Zhang et al. [15] demonstrated that the addition of recombinant HMGB1 (rHMGB1) to the lower compartment (the brain parenchymal side) of a Boyden chamber increased the permeability of albumin from the upper compartment (blood side) to the lower (Figure 2). In their experiments, the artificial BBB was composed of endothelial cells, pericytes, and astrocytes. This increase in albumin permeability was associated with the contractile response of vascular endothelial cells and pericytes but not astrocytes [15] (Figure 3). They also revealed that the addition of anti-HMGB1 mAb to the lower compartment, together with rHMGB1, blocked the effects of rHMGB1 on the morphology and function of endothelial cells and pericytes. These results strongly suggest that HMGB1 directly affects the vascular endothelial cells and pericytes in vitro and in vivo. When administered in vivo, anti-HMGB1 mAb may bind to the released HMGB1 and neutralize the action of HMGB1 [14]. This neutralization of HMGB1 probably leads to protection of the BBB, especially when the released HMGB1 exists in close proximity to the vasculatures of the affected brain [25] (Figures 2 and 3). As anti-HMGB1 mAb therapy has been shown to suppress most of the events relevant to brain inflammatory responses after ischemia and hemorrhage-i.e., induction of cytokines, glia activation, and facilitation of immune cell migration $[15,16]$ — it may be possible that the HMGB1 released from neurons and other brain 
cells functions farther upstream than the other components in the inflammation cascade after insult, leading to a disruption of BBB integrity $[26,63]$ (Figure 4 ).

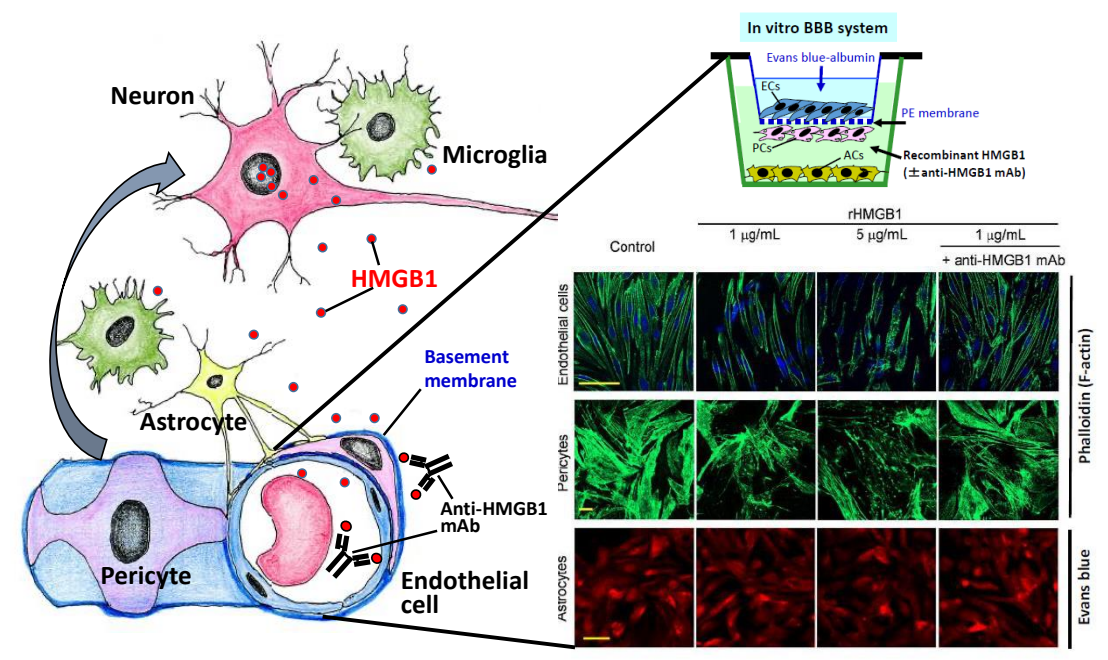

Figure 3. Direct effects of HMGB1 on vascular endothelial cells and pericytes. A rat-reconstituted BBB system composed of vascular endothelial cells, pericytes, and astrocytes (upper right) was used. Recombinant HMGB1 at 1 or $5 \mathrm{mg} / \mathrm{mL}$ was added to the brain side (lower chamber), and the incubation was continued for $60 \mathrm{~min}$. After $1 \mathrm{~h}$ of stimulation with HMGB1, the cells were fixed with paraformaldehyde. Endothelial cells and pericytes were labeled with Alexa-488-phalloidin, and the astrocytes were labeled with Evans blue. The contractile response was observed in endothelial cells and pericytes, which were inhibited by the presence of specific anti-HMGB1 mAb in the lower chamber (modified from Zhang et al., [15]). BBB: blood-brain barrier; HMGB1: high mobility group box-1; mAb: monoclonal antibody.

Pericyte contraction has been reported to play a very important role in ischemia-reperfusion injury because the delivery of oxygen and nutrients via cerebral microcirculation is fundamental to both metabolic demand and proper cerebral function $[64,65]$. The demonstration of an HMGB1-induced contractile response in pericytes in vitro [15] strongly supported the notion that HMGB1 released from different cells in the brain directly affects the pericytes and induces the contraction that leads to a reduction of blood flow in microcirculation in vivo [65]. In addition to the contractile response of pericytes to HMGB1, HMGB1 appears to induce an upregulation of the receptors involved in the contraction of smooth muscle cells in the vessels [16]. The HMGB1 released during a stroke may function as one of the factors that provoke the contraction of microvessels [25].

Intriguingly, the systemic injection of anti-HMGB1 mAb has been shown not only to suppress inflammatory responses in the brain and protect BBB integrity but also to inhibit the translocation and release of HMGB1 itself from neurons [14-16]. It seems likely that the anti-HMGB1 mAb administered in vivo reaches the capillary vessels first, as described above (Figure 3). Therefore, it is possible that the neutralization of HMGB1 that is close to capillary vessels plays an important role in the initial protection of the BBB, followed by the suppression of the subsequent release of HMGB1 from neurons [25]. In other words, it is suggested that there exists a positive feedback loop between HMGB1 mobilization and brain inflammatory responses, including BBB disruption, in the early phase of the insult $[15,16,66]$. (Figure 2). In addition to HMGB1 translocation and the release of HMGB1 from neurons, the release of HMGB1 from microglia and astrocytes has been reported to occur in vitro and in vivo, depending on the conditions [16,67-69]. Thus, an earlier intervention with anti-HMGB1 mAb to block HMGB1 translocation would be expected to produce a better outcome [15,26]. Concerning the therapeutic time window of anti-HMGB1 mAb, 3-6 h after the start of insult was observed in rat hemorrhage and trauma [16,17]. Therefore, the events triggered by HMGB1 may start very quickly after the start of injury onset because HMGB1 is ubiquitously expressed in almost all cells and appears 
to be a ready-made mediator (Figure 4). In the future, it will be very important to identify a primary initiator of HMGB1 mobilization and to clarify the molecular mechanism linking tissue injury and HMGB1 release. In macrophages, the balance between acetylation and deacetylation on HMGB1 has been suggested to control the export of HMGB1 from nuclei to the cytosolic compartment [70-72]. It should be examined whether the same mechanism could be used to balance the same HMGB1 export in any kind of cells, including neural cells.

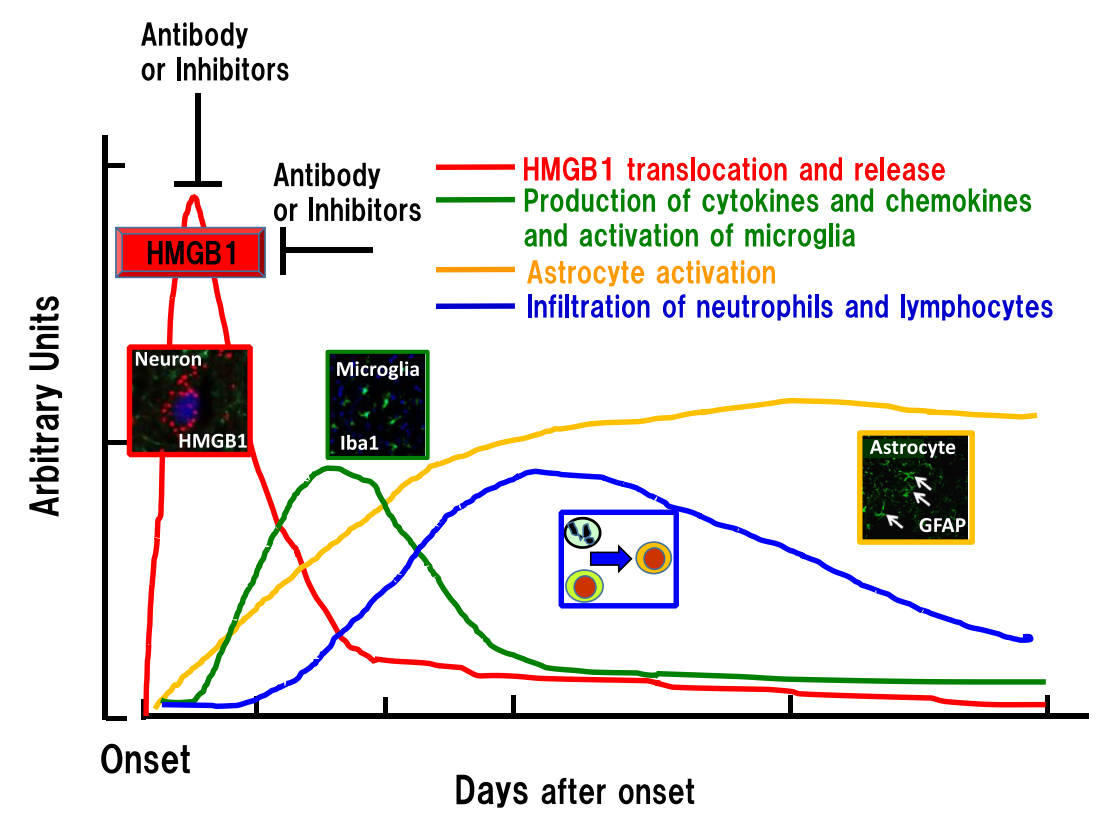

Figure 4. Time-course of inflammation-related events in the penumbra areas after ischemia, hemorrhage, and trauma. HMGB1 translocation and extracellular release form the initial peak to insults, among the known responses, which was followed in succession by microglia activation (cytokine/chemokine production), astrogliosis, and infiltration of immune cells. HMGB1 release may be a very early event that is common to several brain injuries. Inhibition of HMGB1 by the earlier intervention can lead to the diminution of the following inflammatory responses. GFAP: glial fibrillary acidic protein; HMGB1: high mobility group box-1; Iba1: ionized calcium-binding adapter molecule 1 .

Recent work on the translocation of HMGB1 in neurons after ischemic insult indicated that the HMGB1 translocated from nuclei to cytoplasm was colocalized with mitochondria and peroxisomes [73] during the release process. Moreover, HMGB1 was colocalized with Drp-1, a protein involved in the fission of mitochondria, suggesting that HMGB1 also exerts cell-metabolism-modifying effects in these organelles during the translocation process [73].

Matrix metalloproteinases (MMPs) released from pericytes [42,43] have been suggested to be involved in the disruption of the BBB through the digestion of extracellular matrix proteins such as laminin in the basement membrane of capillaries (Figure 1). It is worth mentioning that the mechanism by which HMGB1 upregulates MMP-9 has been investigated in macrophages in peripheral nerve tissue [74].

In addition to neurons and glial cells, vascular endothelial cells may be another origin of extracellular HMGB1 in the brain. Gao et al. [50] reported that a culture of vascular endothelial cells responded to stimuli such as LPS and TNF-a and showed a remarkable translocation of HMGB1 in association with extracellular release without cell death. This release response was almost completely inhibited by the addition of a plasma protein, histidine-rich glycoprotein, at physiological concentration, through the stimulation of C-type lectin receptor-1A on endothelial cells [50]. Based on these findings, it is possible that there might be a receptor-mediated mechanism to control the release of HMGB1 from cells. Further investigations of this issue are warranted. 


\section{Vasospasm after Subarachnoid Hemorrhage}

The treatment for the rupture of intracranial aneurism has been established: clipping of aneurysm or coil embolism. Over the last few decades, however, delayed cerebral ischemia (DCI) due to vasospasm has been one of the major causes of morbidity and mortality in patients with ruptured cerebral aneurysms $[46,75,76]$. Delayed cerebral vasospasm (DCV) usually develops 7 to 14 days after subarachnoid hemorrhage (SAH). A growing number of reports have suggested possible mechanisms for the vasospasm in experimental animal models [77-79]. However, a reliable treatment that controls the vasospasm has not been established [80-82]. Numerous clinical trials [83] have evaluated the effects of antagonists for receptors that may be involved in the contractile response of smooth muscle cells in the arterial wall. In addition to these antagonists, calcium channel inhibitors, antiplatelets, statins, and the rho kinase inhibitor fasudil are also candidate drugs for controlling the contractile machinery in smooth muscle cells [78], but there remains insufficient evidence to include any of these agents in the treatment guidelines for vasospasm. Collectively, the above results suggest that a complex mechanism involving inflammatory processes underlies both DCI and vasospasm [80].

In a clinical study, it was shown that HMGB1 levels in the CSF after SAH were correlated with those of IL-6 and TNF-a and that the elevation of HMGB1 in the CSF reflected the level of severity in patients [59]. Thus, considerable evidence suggests the involvement of inflammation in vasospasms after SAH [84-86]. Haruma et al. [87] demonstrated that HMGB1 translocation and release, along with marked and persistent vasoconstriction, occurred in smooth muscle cells in the basilar arteries of rats in an autologous blood-injection model of SAH. This vasoconstriction was associated with an increase in expression of several receptor mRNAs in the arterial wall that may be involved in the contractile response of the basilar artery [87]. Post-treatment with anti-HMGB1 $\mathrm{mAb}$ efficiently inhibited the vasospasm, in association with a suppression of the mobilization of HMGB1 from smooth muscle cells and upregulation of vasoconstriction-related receptors in the artery [87]. Some inflammatory processes, including the induction of proinflammatory cytokines and the upregulation of RAGE and TLR-4/2, occur in the vascular wall of the basilar artery after $\mathrm{SAH}$, and these were also inhibited by anti-HMGB1 mAb [87] and glycyrrhizin [88], an inhibitor of HMGB1 mobilization. Thus, HMGB1 mobilization, inflammatory responses, and the induction of the arterial contractile state may be interrelated. The strong inhibitory effects of anti-HMGB1 mAb on vasospasms after SAH strongly suggest the involvement of HMGB1 in the induction of the vasocontractile state in the cerebral arteries of the brain after SAH [87]. Since the induction of hyper-responsiveness to thrombin receptor stimulation was reported in a DCI animal model $[89,90]$, the enhancement of responsiveness to thrombin by HMGB1 may be an important factor for the development of vasoconstriction $[87,89,90]$. Therefore, the mobilization of HMGB1 from vascular smooth muscles may be the event farthest upstream among the cascade of events leading to persistent vasospasm $[87,91]$. Treatment with anti-HMGB1 mAb may be a preventive therapy for delayed vasospasm in the subacute phase after $\mathrm{SAH}$, blocking the procontractile state of the arterial walls.

\section{Traumatic Brain Injury and BBB Disruption}

Traffic accidents with traumatic brain injury are one of the leading causes of death in younger generations. The main reason for death after traumatic brain injury is brain swelling, in association with brain herniation and hypoperfusion (hypoxia) of brain tissue, leading to the dysregulation of respiratory and cardiovascular centers. Although it has been speculated that the mechanism for brain swelling might be common to different types of brain injuries, it is important to examine in detail whether a release of HMGB1 occurs after traumatic brain injury and, if so, whether the released HMGB1 is involved in the subsequent disruption of the BBB. It was reported that the plasma [92] and CSF levels [93] of HMGB1 increased significantly in patients with brain trauma and that the elevated levels predicted the outcome of patients. Okuma et al. [17] showed that HMGB1 release from neurons occurred within several hours after fluid percussion injury in rats. They mentioned that the immunohistochemical staining pattern of HMGB1 in neurons in traumatic brain injury was 
not distinguishable from that in the ischemic brain. Anti-HMGB1 mAb therapy maintained the BBB structure under electron microscopy at the affected area and dramatically inhibited brain edema detected by T2-weighted MRI and albumin leakage. Thus, anti-HMGB1 mAb therapy protected BBB disruption morphologically and functionally. As in the case of brain injury induced by ischemia, anti-HMGB1 $\mathrm{mAb}$ inhibited the activation of glia cells and the expression of proinflammatory cytokines, as well as inflammation-related factors $[14,15]$. These effects of anti-HMGB1 mAb on traumatic brain injury were shared by other HMGB1 inhibitors [18,94-96], confirming the usefulness of treatments targeting HMGB1 against traumatic brain injury to prevent BBB disruption and brain edema. The analysis of receptors involved in the action of HMGB1 using receptor-knockout mice implied that RAGE and TLR-4 may play roles in the action of HMGB1 [17]. Anti-HMGB1 mAb therapy was applicable to spinal cord injury in a contusion animal model $[97,98]$. Prior treatment with anti-HMGB1 mAb in mice transplanted with human iPS-derived neuronal stem cells yielded a dramatic improvement in locomotion recovery after spinal cord injury [98]. The combination therapy produced synergistic effects on the contusion-induced spinal cord injury in mice. The beneficial effects of anti-HMGB1 mAb probably come from the inhibition of the initial formation of edema at the injured site and subsequent suppression of glial cell activation $[97,98]$ because there was a therapeutic time window of $6 \mathrm{~h}$ for anti-HMGB1 treatment in this animal model [97], which was comparable to that of hemorrhage brain injury in rats [16]. These results strongly suggest that HMGB1 exerts BBB-disrupting effects at the very acute phase of brain injuries $[25,26]$ (Figure 4). A recent study using conditional- and global-knockout mice of HMGB1 implied that HMGB1 may play different roles, intracellularly and extracellularly, in a time-dependent and site-specific manner [99].

\section{Epilepsy and BBB Disruption}

Epilepsy is a neurological disorder with recurrent seizures. Antiepileptic drugs are used to manage most cases of epilepsy. The majority of antiepileptic drugs currently used in clinical settings function by reducing brain excitability or by enhancing inhibition via the manipulation of ion channels. The side effects of antiepileptic drugs are often unavoidable, and about $30 \%$ of patients are resistant to current therapies. Therefore, novel cutting edge approaches to epilepsy and epileptogenesis research have been actively sought, with the attendant goal of developing new and more effective drugs [100].

There is increasing evidence suggesting the fundamental roles of inflammatory responses in the initiation of status epilepticus and epileptogenesis [101-104]. Maroso et al. [105] first demonstrated that kainate injections into the dorsal hippocampus elicited epileptic seizures through the release of HMGB1 from astrocytes, stimulation of TLR-4 in neurons, and inflammatory responses by the activation of microglia [105]. Baram's group reported that HMGB1 translocation occurred in the amygdala and hippocampus during experimental febrile status epilepticus $[106,107]$. These findings strongly suggest the involvement of HMGB1 in status epilepticus in experimental animals. Fu et al. [21] observed a marked translocation of HMGB1 in hippocampal and cerebral cortex neurons after systemic injections of pilocarpine and a remarkable inhibition of HMGB1 translocation by systemic injections of anti-HMGB1 mAb, leading to the suppression of status epilepticus. Zhao et al. [108] showed that treatment by systemic injections of anti-HMGB1 mAb produced beneficial effects on four kinds of epileptic animal models, i.e., maximal electroshock-induced, kainate-induced, and picrotoxin-induced convulsions and chronic seizure [108]. It was also demonstrated that superfusion of anti-HMGB1 mAb on the surface of brain slices derived from patients with repeated epilepsy [108] inhibited epileptiform activity in the brain slices. Another group reported that mitochondrial translocation of HMGB1 from nuclei in neurons by epileptic stimuli facilitated neuronal cell death $[109,110]$. Taking these results together, we speculate that the HMGB1 released from different sources in response to epileptogenic stimuli may mediate the specific processes leading to status epilepticus, with increased neuronal excitability, including glutamate release, upregulation of IL-1b, TNF-a, TLR-4, and disruption of the BBB $[21,25,111,112]$. Moreover, Zhao et al. [113] demonstrated that neutralization of HMGB1 with $\mathrm{mAb}$ inhibited a diazepam-resistant status epilepticus model, and this inhibition was mediated by a 
TLR-4-dependent pathway. Most of the antiepileptics currently available are activators or inhibitors of ion channels in the plasma membrane. Anti-HMGB1 mAb therapy or HMGB1-release inhibitors may provide an alternative approach to the control of epilepsy and epileptogenesis [114,115]. Nass et al. [116] determined the plasma levels of HMGB1, MMP-9, and ICAM-1 after a single generalized convulsive seizure in epileptic patients. They observed a significant elevation of all these factors and suggested the presence of brain inflammation with BBB disruption even after a single seizure. It is worth mentioning that HMGB1 might be involved in P-glycoprotein expression during status epilepticus, which is related to drug resistance $[117,118]$.

One of the common features of brain injuries induced by ischemia, hemorrhage, trauma, and epilepsy may be BBB dysfunction or disruption. In fact, there is a large body of data from animal model experiments showing an increase in BBB permeability after injury by using different types of tracers of diverse size. Among these tracers, an albumin-binding tracer dye, Evans blue, is commonly used and convenient, and its distribution was demonstrated to merge with the albumin leakage area [17]. The disruption of BBB integrity should involve many processes, including dearrangement of tight junction structures between endothelial cells, lesions of pericytes, digestion of the basement membrane of capillaries, swelling and detachment of astrocyte endfeet from the basement membrane, microglia activation, migration of immune cells from circulation, and release of humoral factors from peripheral tissues. These morphological and functional changes of the BBB should accompany the changes in the gene expression of component cells, cellular signal transduction, and phenotypes of cells. In this respect, little is known about the direct effects of HMGB1 on these component cells in vitro or in vivo. Further studies will be needed to clarify these matters.

\section{Neurodegenerative Disease and BBB Disruption}

Lesions of the cerebral vessels and disruption of the BBB have been suggested to be involved in neurodegenerative diseases, including Alzheimer's disease, Parkinson's disease, amyotrophic lateral sclerosis, and multiple sclerosis [3,24,119]. A familial-type mutation of a specific gene may facilitate the aggregation of b-amyloid, a-synuclein, and SOD1. In addition to the impairment of clearance of these aggregates, there might exist inflammation-related responses that induce vascular complications, including BBB disruption $[24,119,120]$.

There is increasing evidence that suggests the involvement of BBB dysfunction or disruption in vascular events, especially in Alzheimer's disease [120-123]. The receptor for advanced glycation endproduct (RAGE) was identified as the receptor for AGEs and has been thought to mediate the deleterious effects of AGEs in diabetic patients, with complications of the blood vessels. RAGE functions as a pattern-recognition receptor for a diverse range of factors, and both amyloid b-peptide and HMGB1 are ligands for RAGE. RAGE is expressed on different kinds of cells in the brain, including brain capillaries. An increase in BBB permeability and the leakage of macromolecules from capillaries were observed in the postmortem brains of Alzheimer's patients [124,125] and an in-vitro BBB model $[126,127]$. These findings strongly imply that maintenance of the integrity of the BBB is impaired in Alzheimer's disease. In a mouse model of Alzheimer's disease, a similar pattern of BBB breakdown was observed before the manifestation of impairment of cognitive functions [128]. Thus, it might be possible that the disruption of the BBB precedes neuronal cell degeneration. In RAGE-knockout mice, the impairment in synaptic functions was reduced compared with that in wild-type mice $[129,130]$, suggesting the involvement of RAGE in the occurrence of symptoms of Alzheimer's disease. In addition to RAGE, b-amyloid, and LPS, HMGB1 may also play an important role in the activation of RAGE in the brain. It is noteworthy that many reports have suggested the involvement of circulating HMGB1, released from peripheral tissues, in consciousness reduction and impairment in higher cognitive functions. This issue will be described in a later section.

Fujita et al. [131] searched for genes that were upregulated in both the brains of patients with Alzheimer's disease and a mouse model of Alzheimer's disease and identified HMGB1 as one such gene. They demonstrated that HMGB1 may play a role in the aggregation of beta-amyloid peptide in 
Alzheimer's model mice through the activation of the PKC isoform [131,132]. They also found that chronic treatment with anti-HMGB1 mAb had preventive effects against both beta-amyloid aggregation and cognitive impairment in this animal model. These results imply the involvement of extracellular HMGB1 in the neurogenerative processes in Alzheimer's disease.

Concerning Parkinson's disease, systemic administration of anti-HMGB1 mAb inhibited dopaminergic neuronal cell death induced by microinjections of 6-OH dopamine into rat striatum through the suppression of inflammation and the production of reactive oxygen species, in association with protection against BBB disruption [67]. Santoro et al. [133] reported that neutralizing antibodies against HMGB1, as well as glycyrrhizin, inhibited dopamine neuron death induced by MPTP. Taken together, these results suggest that HMGB1 facilitates the cascade of events triggered by dopaminergic neurotoxins. It is worth noting that endogenous intracellular HMGB1 conversely promoted the degradation of a-synuclein by autophagy in the neuroblastoma cell line PC12 [134,135].

There is considerable evidence suggesting the involvement of HMGB1 in the development of multiple sclerosis or neuromyelitis optica [136-140]. However, the specific contribution of HMGB1 to pathogenesis remains to be determined.

Depression, a disorder of mood, is a common disease condition in psychiatric clinics [141]. Although there are several hypotheses concerning the pathophysiology of depression, such as the idea that depression arises from an aminergic neuron disorder, hypercorticosteroidemia due to chronic stress, or insufficiency of BDNF, the mechanistic events in depression remain to be determined. There are increasing reports that suggest that inflammation in the brain is involved in the development of the depressive state [142-145]. Hisaoka-Nakashima et al. [146] reported that HMGB1-mediated microglial activation induced anxiodepressive-like behaviors in mice with neuropathic pain. This suggests that there is a close relationship between HMGB1-induced brain inflammation and the depressive state. It might be very interesting to pursue this potential association.

\section{HMGB1 Release from Vascular Endothelial Cells In Vitro}

Using a vascular endothelial cell culture, HMGB1 translocation was examined after stimulation with LPS and TNF-a [50]. These stimuli induced the translocation of HMGB1 from nuclei to the extracellular milieu through the cytosolic compartment [50]. The release was dependent on NF-kB activation. It was shown that the recombinant HMGB1 (rHMGB1) induced the upregulation of adhesion molecules ICAM-1 and VCAM-1 on the surface of vascular endothelial cells in the manner of LPS and TNF-a. The upregulation of adhesion molecules was accompanied by the production of the cytokines IL-8, IL-6, and TNF-a by the cells, which was mediated by NF-kB activation. The stimulation by rHMGB1 was also associated with the upregulation of HMGB1 receptors, namely, toll-like receptor-2/4 and RAGE. Therefore, there might be a self-activation mechanism in endothelial cells that is mediated by HMGB1. It has been speculated that disorders of vascular endothelial cells play a role in severe systemic inflammation, especially under septic conditions. Accordingly, HMGB1 release from vascular endothelial cells may have multiple effects that contribute to the activation of the endothelial cells themselves. It should be pointed out that a plasma protein, histidine-rich glycoprotein [147], antagonized the effects of HMGB1 on vascular endothelial cells [50]. This relationship suggests the fine regulation of the interface between plasma and vascular endothelial cells [50]. Together, these results suggest that HMGB1 induced multiple effects that directly stimulated vascular endothelial cells in the same manner as LPS and TNF-a.

\section{The Relationship between Peripheral Inflammation and BBB}

As mentioned in the section on stroke, the plasma or CSF levels of HMGB1 increase significantly depending on the severity of brain injury. This increase may promote lung inflammation because it is well known that a portion of patients with stroke develop pneumonia concomitantly [148-150]. On the other hand, it may be that the inverse sequence occurs, with peripheral inflammation influencing the CNS [151,152]. A rat model of postischemic infection treated with LPS exhibited an exacerbation of 
infarct formation [153], indicating amplification of brain inflammation through the systemic load of endotoxins. In humans, it was demonstrated that peripheral surgery induced BBB disruption [154,155]. Influenza pneumonia can induce BBB breakdown by the load of endotoxins, which may be mediated by HMGB1 [156]. Thus, there are many reports indicating a relationship between peripheral inflammation and BBB disruption [157]. Among cases of peripheral inflammation, the most dramatic may be those with septic encephalopathy, which is characterized by an evident increase in the capillary permeability of brain vessels and brain swelling, leading to a reduction in consciousness [38].

In COVID-19, delirium and encephalopathy have been reported to be observed in more than $80 \%$ of patients [158]. Another group determined the plasma levels of S100 A8/9 and HMGB1 in the circulation and found a correlation between the elevation of S100A8/9 and HMGB1 and the clinical severity of patients [159]. Thus, it is likely that the elevation of these DAMPs, reflecting peripheral inflammation, may, in part, contribute to the occurrence of CNS symptoms through the effects on the BBB and blood cells [160].

HMGB1 binds to lipopolysaccharides, and the HMGB1-LPS complex appears to be transported into lysosomes in hepatocytes, leading to the activation of caspase-11 and IL-1 secretions [39]. It is noteworthy that HMGB1 plays proinflammatory roles through plural pathways.

\section{Therapeutic Methods Targeting HMGB1}

There are several classes of drugs that have therapeutic potential for inhibiting the effects of HMGB1 in the brain. Table 1 summarizes the different approaches and their mechanisms: box-A proteins, antagonists for HMGB1 receptors; neutralizing mAbs, binding aptamers or peptides; siRNA for HMGB1; inhibitors of HMGB1 secretion. Concerning the inhibitors of HMGB1 secretion, many kinds of herb-derived substances have been reported, including glycyrrhizin. This strongly suggests that the anti-inflammatory effects of some of the prescriptions in traditional medicine may be, in part, ascribable to the presence of HMGB1 inhibitors in the complex compositions.

Table 1. Effects of different HMGB1 inhibitors on brain inflammation and BBB disruption.

\begin{tabular}{|c|c|c|c|}
\hline Thrapeutics & Models & Animals, Route & Reference \\
\hline \multirow[t]{2}{*}{ Box-A protein } & Meningitis & Mice, i.p. & Hohne et al. [161] \\
\hline & TBI & Mice, i.v. & Yang et al. [162] \\
\hline \multirow[t]{6}{*}{ Anti-HMGB1 mAb } & $\mathrm{MCAO} / \mathrm{R}$ & Rats, i.v. & Liu et al. [14] \\
\hline & TBI & Rats, i.v. & Okuma et al. [17] \\
\hline & Hemorrhage & Rats, i.v. & Wang et al. [16] \\
\hline & TSCI & Mice, i.p. & Uezono et al. [98] \\
\hline & SAH & Rats, i.v. & Haruma et al. [87] \\
\hline & Epilepsy & Mice, i.v. & Fu et al. [21] \\
\hline \multirow[t]{2}{*}{ siRNA } & $\mathrm{MCAO} / \mathrm{R}$ & Rats, i.c.i & Kim et al. [51] \\
\hline & $\mathrm{MCAO} / \mathrm{R}$ & Rats, i.n. & Kim et al. [163] \\
\hline Binding peptide & $\mathrm{MCAO} / \mathrm{R}$ & Rats, i.n. & Kim et al. [164] \\
\hline \multirow{4}{*}{ Ethyl pyruvate } & $\mathrm{MCAO} / \mathrm{R}$ & Rats, i.p. & Yu et al. [165] \\
\hline & $\mathrm{SC}$ ischemia & Rabbits, i.v. & Wang et al. [166] \\
\hline & TBI & Rats, i.p. & Su et al. [95] \\
\hline & Hemorrhage & Rats, i.p. & Lei et al. [56] \\
\hline \multicolumn{4}{|l|}{ Release inhibitors } \\
\hline \multirow[t]{6}{*}{ Glyccyrrhizin } & $\mathrm{MCAO} / \mathrm{R}$ & Rats, i.v. & Kim et al. [167] \\
\hline & $\mathrm{I} / \mathrm{R}$ & Mice, i.v. & Ni et al. [168] \\
\hline & TBI & Rats, Mice, i.v. & Okuma et al. [18] \\
\hline & TSCI & Rats, i.v. & Gong et al. [169] \\
\hline & Hemorrhage & Rats, i.p. & Ohnishi et al. [170] \\
\hline & SAH & Rats, i.p & Li et al. [88] \\
\hline Tanshinone II & pMCAO & Rats, i.p. & Wang et al. [171] \\
\hline Berberine & $\mathrm{MCAO} / \mathrm{R}$ & Mice, i.g. & Zhu et al. [172] \\
\hline Ginsenosides & $\mathrm{MCAO} / \mathrm{R}$ & Rats, i.g. & Xie et al. [173] \\
\hline
\end{tabular}


Table 1. Cont

\begin{tabular}{cccc}
\hline Thrapeutics & Models & Animals, Route & Reference \\
\hline Ursolic acid & MCAO/R & Rats, i.g. & Wang et al. [174] \\
Others & & Rats, i.p. & Chen et al. [175] \\
Omega-3 PUFA & TBI & Mice, i.v. & Nakamura et al. [176] \\
\hline Soluble thrombomodulin & MCAO/R & .
\end{tabular}

$\mathrm{MCAO/R:} \mathrm{middle} \mathrm{cerebral} \mathrm{artery} \mathrm{occlusion} \mathrm{and} \mathrm{reperfusion;} \mathrm{pMCAO:} \mathrm{permanent} \mathrm{middle} \mathrm{cerebral} \mathrm{artery} \mathrm{occlusion;}$ TBI: traumatic brain injury; TSCI: traumatic spinal cord injury; SAH: subarachnoid hemorrhage; SC ischemia: spinal cord ischemia; i.p.: intraperitoneal; i.v.: intravenous; i.n.: intranasal; i.g.: intragastric; PUFA: polyunsaturated fatty acid.

\section{Conclusions}

Inflammatory responses after cerebral ischemia, hemorrhage, trauma, or epilepsy are closely associated with BBB dysfunction and disruption. During the inflammatory processes, HMGB1 may be released extracellularly from neurons, glia, or endothelial cells, depending on the situation (Figure 5). Anti-HMGB1 mAb therapy and HMGB1 inhibitors were demonstrated to be beneficial within a specific therapeutic time window for different kinds of inflammatory diseases in animal models, especially those containing BBB disruption. In other words, the extracellular release of HMGB1 may play very important roles in triggering the initial inflammatory responses through the stimulation of multiple receptors, leading to BBB disruption. Therefore, therapies with anti-HMGB1 mAb and inhibitors of HMGB1 release may provide novel approaches to the treatment of brain inflammatory diseases associated with BBB disruption. A clear understanding of the mutual relationship between peripheral and CNS inflammation and the roles of HMGB1 in mediating these processes must await further studies.

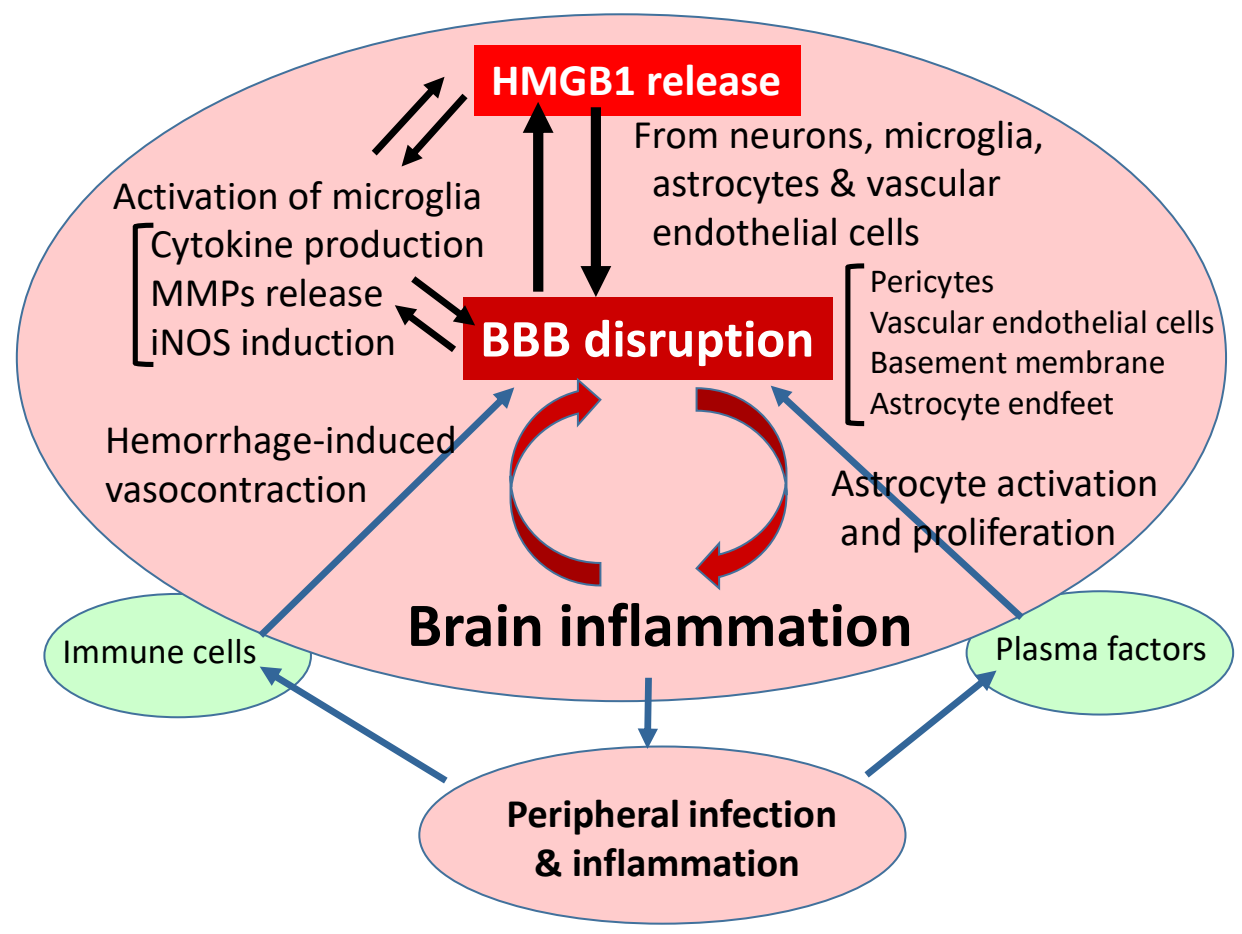

Figure 5. Flow diagram of relationship between HMGB1 release and BBB disruption. As described in the text, HMGB1 release is common to different kinds of injuries induced by ischemia/reperfusion, hemorrhage,trauma, and epilepsy, leading to BBB disruption through direct and indirect pathways. The peripheral inflammation caused by infection may exacerbate BBB disruption. Conversely, brain injuries may induce a vulnerability to infection in patients. BBB: blood-brain barrier; HMGB1: high mobility group box-1; iNOS: inducible nitric oxide synthase; MMPs: matrix metallo proteinases. 
Author Contributions: M.N. wrote the draft manuscript and designed the figures and tables; all coauthors (D.W., D.O., and H.W.) contributed substantially with revisions and improvement of the manuscript. All authors have read and agreed to the published version of the manuscript.

Funding: The work was supported in part by a Grant-in-Aid for Scientific Research (no. 19H03408 to M.N.) from the Japan Society for the Promotion of Science (JSPS).

Conflicts of Interest: The authors declare no conflict of interest.

\section{Abbreviations}

BBB: blood-brain barrier; CNS: central nervous system; CBF: cerebral blood flow; CSF: cerebrospinal fluid; DAMP: damage-associated molecular pattern; DCI; delayed cerebral ischemia; DCV: delayed cerebral vasospasm; HMGB1: high mobility group box-1; mAb: monoclonal antibody; MCAO: middle cerebral artery occlusion; NVU: neurovascular unit; RAGE: receptor for advanced glycation endproduct; rHMGB1: recombinant HMGB1; SAH: subarachnoid hemorrhage.

\section{References}

1. Iadecola, C. The pathobiology of vascular dementia. Neuron 2013, 80, 844-866. [CrossRef] [PubMed]

2. Ahmad, A.; Patel, V.; Xiao, J.; Khan, M.M. The Role of Neurovascular System in Neurodegenerative Diseases. Mol. Neurobiol. 2020, 57, 4373-4393. [CrossRef] [PubMed]

3. Sweeney, M.D.; Zhao, Z.; Montagne, A.; Nelson, A.R.; Zlokovic, B.V. Blood-Brain Barrier: From Physiology to Disease and Back. Physiol. Rev. 2019, 99, 21-78. [CrossRef]

4. Abbott, N.J.; Patabendige, A.A.; Dolman, D.E.; Yusof, S.R.; Begley, D.J. Structure and function of the blood-brain barrier. Neurobiol. Dis. 2010, 37, 13-25. [CrossRef] [PubMed]

5. Shichita, T.; Sakaguchi, R.; Suzuki, M.; Yoshimura, A. Post-ischemic inflammation in the brain. Front. Immunol. 2012, 3, 132. [CrossRef]

6. Zhao, Z.; Nelson, A.R.; Betsholtz, C.; Zlokovic, B.V. Establishment and Dysfunction of the Blood-Brain Barrier. Cell 2015, 163, 1064-1078. [CrossRef]

7. Armulik, A.; Genove, G.; Betsholtz, C. Pericytes: Developmental, physiological, and pathological perspectives, problems, and promises. Dev. Cell 2011, 21, 193-215. [CrossRef]

8. Al-Majdoub, Z.M.; Al Feteisi, H.; Achour, B.; Warwood, S.; Neuhoff, S.; Rostami-Hodjegan, A.; Barber, J. Proteomic Quantification of Human Blood-Brain Barrier SLC and ABC Transporters in Healthy Individuals and Dementia Patients. Mol. Pharm. 2019, 16, 1220-1233. [CrossRef]

9. Al Feteisi, H.; Al-Majdoub, Z.M.; Achour, B.; Couto, N.; Rostami-Hodjegan, A.; Barber, J. Identification and quantification of blood-brain barrier transporters in isolated rat brain microvessels. J. Neurochem. 2018, 146, 670-685. [CrossRef]

10. Omori, K.; Tachikawa, M.; Hirose, S.; Taii, A.; Akanuma, S.I.; Hosoya, K.I.; Terasaki, T. Developmental changes in transporter and receptor protein expression levels at the rat blood-brain barrier based on quantitative targeted absolute proteomics. Drug Metab. Pharmacokinet. 2020, 35, 117-123. [CrossRef]

11. Armulik, A.; Genove, G.; Mae, M.; Nisancioglu, M.H.; Wallgard, E.; Niaudet, C.; He, L.; Norlin, J.; Lindblom, P.; Strittmatter, K.; et al. Pericytes regulate the blood-brain barrier. Nature 2010, 468, 557-561. [CrossRef] [PubMed]

12. Cai, W.; Liu, H.; Zhao, J.; Chen, L.Y.; Chen, J.; Lu, Z.; Hu, X. Pericytes in Brain Injury and Repair After Ischemic Stroke. Transl. Stroke Res. 2017, 8, 107-121. [CrossRef] [PubMed]

13. Sweeney, M.D.; Ayyadurai, S.; Zlokovic, B.V. Pericytes of the neurovascular unit: Key functions and signaling pathways. Nat. Neurosci. 2016, 19, 771-783. [CrossRef]

14. Liu, K.; Mori, S.; Takahashi, H.K.; Tomono, Y.; Wake, H.; Kanke, T.; Sato, Y.; Hiraga, N.; Adachi, N.; Yoshino, T.; et al. Anti-high mobility group box 1 monoclonal antibody ameliorates brain infarction induced by transient ischemia in rats. FASEB J. 2007, 21, 3904-3916. [CrossRef] [PubMed]

15. Zhang, J.; Takahashi, H.K.; Liu, K.; Wake, H.; Liu, R.; Maruo, T.; Date, I.; Yoshino, T.; Ohtsuka, A.; Mori, S.; et al. Anti-high mobility group box-1 monoclonal antibody protects the blood-brain barrier from ischemia-induced disruption in rats. Stroke A J. Cereb. Circ. 2011, 42, 1420-1428. [CrossRef]

16. Wang, D.; Liu, K.; Wake, H.; Teshigawara, K.; Mori, S.; Nishibori, M. Anti-high mobility group box-1 (HMGB1) antibody inhibits hemorrhage-induced brain injury and improved neurological deficits in rats. Sci. Rep. 2017, 7, 46243. [CrossRef] [PubMed] 
17. Okuma, Y.; Liu, K.; Wake, H.; Zhang, J.; Maruo, T.; Date, I.; Yoshino, T.; Ohtsuka, A.; Otani, N.; Tomura, S.; et al. Anti-high mobility group box-1 antibody therapy for traumatic brain injury. Ann. Neurol. 2012, 72, 373-384. [CrossRef]

18. Okuma, Y.; Liu, K.; Wake, H.; Liu, R.; Nishimura, Y.; Hui, Z.; Teshigawara, K.; Haruma, J.; Yamamoto, Y.; Yamamoto, H.; et al. Glycyrrhizin inhibits traumatic brain injury by reducing HMGB1-RAGE interaction. Neuropharmacology 2014, 85, 18-26. [CrossRef]

19. Shlosberg, D.; Benifla, M.; Kaufer, D.; Friedman, A. Blood-brain barrier breakdown as a therapeutic target in traumatic brain injury. Nat. Rev. Neurol. 2010, 6, 393-403. [CrossRef]

20. Dadas, A.; Janigro, D. Breakdown of blood brain barrier as a mechanism of post-traumatic epilepsy. Neurobiol. Dis. 2019, 123, 20-26. [CrossRef]

21. Fu, L.; Liu, K.; Wake, H.; Teshigawara, K.; Yoshino, T.; Takahashi, H.; Mori, S.; Nishibori, M. Therapeutic effects of anti-HMGB1 monoclonal antibody on pilocarpine-induced status epilepticus in mice. Sci. Rep. 2017, 7, 1179. [CrossRef] [PubMed]

22. Seiffert, E.; Dreier, J.P.; Ivens, S.; Bechmann, I.; Tomkins, O.; Heinemann, U.; Friedman, A. Lasting blood-brain barrier disruption induces epileptic focus in the rat somatosensory cortex. J. Neurosci. 2004, 24, 7829-7836. [CrossRef] [PubMed]

23. van Vliet, E.A.; Araujo, S.D.; Redeker, S.; van Schaik, R.; Aronica, E.; Gorter, J.A. Blood-brain barrier leakage may lead to progression of temporal lobe epilepsy. Brain 2007, 130, 521-534. [CrossRef] [PubMed]

24. Iadecola, C. The Neurovascular Unit Coming of Age: A Journey through Neurovascular Coupling in Health and Disease. Neuron 2017, 96, 17-42. [CrossRef] [PubMed]

25. Nishibori, M.; Mori, S.; Takahashi, H.K. Anti-HMGB1 monoclonal antibody therapy for a wide range of CNS and PNS diseases. J. Pharmacol. Sci. 2019, 140, 94-101. [CrossRef] [PubMed]

26. Shichita, T.; Hasegawa, E.; Kimura, A.; Morita, R.; Sakaguchi, R.; Takada, I.; Sekiya, T.; Ooboshi, H.; Kitazono, T.; Yanagawa, T.; et al. Peroxiredoxin family proteins are key initiators of post-ischemic inflammation in the brain. Nat. Med. 2012, 18, 911-917. [CrossRef]

27. Erickson, M.A.; Banks, W.A. Neuroimmune Axes of the Blood-Brain Barriers and Blood-Brain Interfaces: Bases for Physiological Regulation, Disease States, and Pharmacological Interventions. Pharm. Rev. 2018, 70, 278-314. [CrossRef]

28. Konoeda, F.; Shichita, T.; Yoshida, H.; Sugiyama, Y.; Muto, G.; Hasegawa, E.; Morita, R.; Suzuki, N.; Yoshimura, A. Therapeutic effect of IL-12/23 and their signaling pathway blockade on brain ischemia model. Biochem. Biophys. Res. Commun. 2010, 402, 500-506. [CrossRef]

29. Rauvala, H.; Pihlaskari, R. Isolation and Some Characteristics of an Adhesive Factor of Brain That Enhances Neurite Outgrowth in Central Neurons. J. Biol. Chem. 1987, 262, 16625-16635.

30. Merenmies, J.; Pihlaskari, R.; Laitinen, J.; Wartiovaara, J.; Rauvala, H. 30-kDa heparin-binding protein of brain (amphoterin) involved in neurite outgrowth. Amino acid sequence and localization in the filopodia of the advancing plasma membrane. J. Biol. Chem. 1991, 266, 16722-16729.

31. Parkkinen, J.; Raulo, E.; Merenmies, J.; Nolo, R.; Kajander, E.O.; Baumann, M.; Rauvala, H. Amphoterin, the 30-kDa protein in a family of HMG1-type polypeptides. Enhanced expression in transformed cells, leading edge localization, and interactions with plasminogen activation. J. Biol. Chem. 1993, 268, 19726-19738. [PubMed]

32. Wang, H.C.; Bloom, O.; Zhang, M.H.; Vishnubhakat, J.M.; Ombrellino, M.; Che, J.T.; Frazier, A.; Yang, H.; Ivanova, S.; Borovikova, L.; et al. HMG-1 as a late mediator of endotoxin lethality in mice. Science 1999, 285, 248-251. [CrossRef] [PubMed]

33. Andersson, U.; Tracey, K.J. HMGB1 Is a Therapeutic Target for Sterile Inflammation and Infection. Annu. Rev. Immunol. 2011, 29, 139-162. [CrossRef] [PubMed]

34. Chen, G.Y.; Nunez, G. Sterile inflammation: Sensing and reacting to damage. Nat. Rev. Immunol. 2010, 10, 826-837. [CrossRef]

35. Lotze, M.T.; Tracey, K.J. High-mobility group box 1 protein (HMGB1): Nuclear weapon in the immune arsenal. Nat. Rev. Immunol. 2005, 5, 331-342. [CrossRef]

36. Scaffidi, P.; Misteli, T.; Bianchi, M.E. Release of chromatin protein HMGB1 by necrotic cells triggers inflammation. Nature 2002, 418, 191-195. [CrossRef] [PubMed]

37. Yang, H.; Wang, H.; Andersson, U. Targeting Inflammation Driven by HMGB1. Front. Immunol. 2020, 11, 484. [CrossRef] 
38. Andersson, U.; Ottestad, W.; Tracey, K.J. Extracellular HMGB1: A therapeutic target in severe pulmonary inflammation including COVID-19? Mol. Med. 2020, 26, 42. [CrossRef] [PubMed]

39. Deng, M.; Tang, Y.; Li, W.; Wang, X.; Zhang, R.; Zhang, X.; Zhao, X.; Liu, J.; Tang, C.; Liu, Z.; et al. The Endotoxin Delivery Protein HMGB1 Mediates Caspase-11-Dependent Lethality in Sepsis. Immunity 2018, 49, 740-753. [CrossRef]

40. Kaneda, Y.; Iwai, K.; Uchida, T. Introduction and expression of the human insulin gene in adult rat liver. J. Biol. Chem. 1989, 264, 12126-12129.

41. Machida, T.; Takata, F.; Matsumoto, J.; Takenoshita, H.; Kimura, I.; Yamauchi, A.; Dohgu, S.; Kataoka, Y. Brain pericytes are the most thrombin-sensitive matrix metalloproteinase-9-releasing cell type constituting the blood-brain barrier in vitro. Neurosci. Lett. 2015, 599, 109-114. [CrossRef] [PubMed]

42. Takata, F.; Dohgu, S.; Matsumoto, J.; Takahashi, H.; Machida, T.; Wakigawa, T.; Harada, E.; Miyaji, H.; Koga, M.; Nishioku, T.; et al. Brain pericytes among cells constituting the blood-brain barrier are highly sensitive to tumor necrosis factor-alpha, releasing matrix metalloproteinase- 9 and migrating in vitro. $J$. Neuroinflamm. 2011, 8, 106. [CrossRef] [PubMed]

43. Underly, R.G.; Levy, M.; Hartmann, D.A.; Grant, R.I.; Watson, A.N.; Shih, A.Y. Pericytes as Inducers of Rapid, Matrix Metalloproteinase-9-Dependent Capillary Damage during Ischemia. J. Neurosci. 2017, 37, 129-140. [CrossRef] [PubMed]

44. Berthiaume, A.A.; Grant, R.I.; McDowell, K.P.; Underly, R.G.; Hartmann, D.A.; Levy, M.; Bhat, N.R.; Shih, A.Y. Dynamic Remodeling of Pericytes In Vivo Maintains Capillary Coverage in the Adult Mouse Brain. Cell Rep. 2018, 22, 8-16. [CrossRef] [PubMed]

45. Cheng, J.; Korte, N.; Nortley, R.; Sethi, H.; Tang, Y.; Attwell, D. Targeting pericytes for therapeutic approaches to neurological disorders. Acta Neuropathol. 2018, 136, 507-523. [CrossRef] [PubMed]

46. Chen, J.; Luo, Y.; Hui, H.; Cai, T.; Huang, H.; Yang, F.; Feng, J.; Zhang, J.; Yan, X. CD146 coordinates brain endothelial cell-pericyte communication for blood-brain barrier development. Proc. Natl. Acad. Sci. USA 2017, 114, E7622-E7631. [CrossRef] [PubMed]

47. Morris, M.E.; Rodriguez-Cruz, V.; Felmlee, M.A. SLC and ABC Transporters: Expression, Localization, and Species Differences at the Blood-Brain and the Blood-Cerebrospinal Fluid Barriers. AAPS J. 2017, 19, 1317-1331. [CrossRef]

48. Pardridge, W.M. Drug transport across the blood-brain barrier. J. Cereb. Blood Flow Metab. 2012, 32, $1959-1972$. [CrossRef]

49. Abdul Razzak, R.; Florence, G.J.; Gunn-Moore, F.J. Approaches to CNS Drug Delivery with a Focus on Transporter-Mediated Transcytosis. Int. J. Mol. Sci. 2019, 20, 3108. [CrossRef]

50. Gao, S.Z.; Wake, H.; Sakaguchi, M.; Wang, D.L.; Takahashi, Y.; Teshigawara, K.; Zhong, H.; Mori, S.; Liu, K.Y.; Takahashi, H.; et al. Histidine-Rich Glycoprotein Inhibits High-Mobility Group Box-1-Mediated Pathways in Vascular Endothelial Cells through CLEC-1A. iScience 2020, 23. [CrossRef]

51. Kim, J.B.; Sig Choi, J.; Yu, Y.M.; Nam, K.; Piao, C.S.; Kim, S.W.; Lee, M.H.; Han, P.L.; Park, J.S.; Lee, J.K. HMGB1, a novel cytokine-like mediator linking acute neuronal death and delayed neuroinflammation in the postischemic brain. J. Neurosci. J. Soc. Neurosci. 2006, 26, 6413-6421. [CrossRef] [PubMed]

52. Faraco, G.; Fossati, S.; Bianchi, M.E.; Patrone, M.; Pedrazzi, M.; Sparatore, B.; Moroni, F.; Chiarugi, A. High mobility group box 1 protein is released by neural cells upon different stresses and worsens ischemic neurodegeneration in vitro and in vivo. J. Neurochem. 2007, 103, 590-603. [CrossRef] [PubMed]

53. Kim, J.B.; Lim, C.M.; Yu, Y.M.; Lee, J.K. Induction and subcellular localization of high-mobility group box-1 (HMGB1) in the postischemic rat brain. J. Neurosci. Res. 2008, 86, 1125-1131. [CrossRef] [PubMed]

54. Qiu, J.; Nishimura, M.; Wang, Y.; Sims, J.R.; Qiu, S.; Savitz, S.I.; Salomone, S.; Moskowitz, M.A. Early release of HMGB-1 from neurons after the onset of brain ischemia. J. Cereb. Blood Flow Metab. J. Int. Soc. Cereb. Blood Flow Metab. 2008, 28, 927-938. [CrossRef]

55. Chen, X.; Zhang, J.; Kim, B.; Jaitpal, S.; Meng, S.S.; Adjepong, K.; Imamura, S.; Wake, H.; Nishibori, M.; Stopa, E.G.; et al. High-mobility group box-1 translocation and release after hypoxic ischemic brain injury in neonatal rats. Exp. Neurol. 2019, 311, 1-14. [CrossRef]

56. Lei, C.; Lin, S.; Zhang, C.; Tao, W.; Dong, W.; Hao, Z.; Liu, M.; Wu, B. High-mobility group box 1 protein promotes neuroinflammation after intracerebral hemorrhage in rats. Neuroscience 2013, 228, 190-199. [CrossRef] 
57. Tsukagawa, T.; Katsumata, R.; Fujita, M.; Yasui, K.; Akhoon, C.; Ono, K.; Dohi, K.; Aruga, T. Elevated Serum High-Mobility Group Box-1 Protein Level Is Associated with Poor Functional Outcome in Ischemic Stroke. J. Stroke Cerebrovasc. Dis. 2017, 26, 2404-2411. [CrossRef]

58. Zhou, Y.; Xiong, K.L.; Lin, S.; Zhong, Q.; Lu, F.L.; Liang, H.; Li, J.C.; Wang, J.Z.; Yang, Q.W. Elevation of high-mobility group protein box-1 in serum correlates with severity of acute intracerebral hemorrhage. Mediat. Inflamm. 2010, 2010. [CrossRef]

59. Nakahara, T.; Tsuruta, R.; Kaneko, T.; Yamashita, S.; Fujita, M.; Kasaoka, S.; Hashiguchi, T.; Suzuki, M.; Maruyama, I.; Maekawa, T. High-mobility group box 1 protein in CSF of patients with subarachnoid hemorrhage. Neurocrit. Care 2009, 11, 362-368. [CrossRef]

60. Sokol, B.; Wozniak, A.; Jankowski, R.; Jurga, S.; Wasik, N.; Shahid, H.; Grzeskowiak, B. HMGB1 Level in Cerebrospinal Fluid as a Marker of Treatment Outcome in Patients with Acute Hydrocephalus Following Aneurysmal Subarachnoid Hemorrhage. J. Stroke Cerebrovasc. Dis. 2015, 24, 1897-1904. [CrossRef]

61. Sapojnikova, N.; Kartvelishvili, T.; Asatiani, N.; Zinkevich, V.; Kalandadze, I.; Gugutsidze, D.; Shakarishvili, R.; Tsiskaridze, A. Correlation between MMP-9 and extracellular cytokine HMGB1 in prediction of human ischemic stroke outcome. Biochim. Biophys. Acta Mol. Basis Dis. 2014, 1842, 1379-1384. [CrossRef]

62. Wang, J.; Jiang, Y.; Zeng, D.; Zhou, W.; Hong, X. Prognostic value of plasma HMGB1 in ischemic stroke patients with cerebral ischemia-reperfusion injury after intravenous thrombolysis. J. Stroke Cerebrovasc. Dis. J. Natl. Stroke Assoc. 2020, 29, 105055. [CrossRef] [PubMed]

63. Zhang, J.C.; Wu, Y.; Weng, Z.L.; Zhou, T.; Feng, T.; Lin, Y. Glycyrrhizin protects brain against ischemia-reperfusion injury in mice through HMGB1-TLR4-IL-17A signaling pathway. Brain Res. 2014, 1582, 176-186. [CrossRef] [PubMed]

64. Erdener, S.E.; Dalkara, T. Small Vessels Are a Big Problem in Neurodegeneration and Neuroprotection. Front. Neurol. 2019, 10, 889. [CrossRef] [PubMed]

65. Yemisci, M.; Gursoy-Ozdemir, Y.; Vural, A.; Can, A.; Topalkara, K.; Dalkara, T. Pericyte contraction induced by oxidative-nitrative stress impairs capillary reflow despite successful opening of an occluded cerebral artery. Nat. Med. 2009, 15, 1031-1037. [CrossRef] [PubMed]

66. Richard, S.A.; Sackey, M.; Su, Z.; Xu, H. Pivotal neuroinflammatory and therapeutic role of high mobility group box 1 in ischemic stroke. Biosci. Rep. 2017, 37. [CrossRef]

67. Sasaki, T.; Liu, K.; Agari, T.; Yasuhara, T.; Morimoto, J.; Okazaki, M.; Takeuchi, H.; Toyoshima, A.; Sasada, S.; Shinko, A.; et al. Anti-high mobility group box 1 antibody exerts neuroprotection in a rat model of Parkinson's disease. Exp. Neurol. 2016, 275 Pt 1, 220-231. [CrossRef]

68. Shi, Y.; Guo, X.; Zhang, J.; Zhou, H.; Sun, B.; Feng, J. DNA binding protein HMGB1 secreted by activated microglia promotes the apoptosis of hippocampal neurons in diabetes complicated with OSA. Brain Behav. Immun. 2018, 73, 482-492. [CrossRef]

69. Shin, J.H.; Lee, H.K.; Lee, H.B.; Jin, Y.; Lee, J.K. Ethyl pyruvate inhibits HMGB1 phosphorylation and secretion in activated microglia and in the postischemic brain. Neurosci. Lett. 2014, 558, 159-163. [CrossRef]

70. Bonaldi, T.; Talamo, F.; Scaffidi, P.; Ferrera, D.; Porto, A.; Bachi, A.; Rubartelli, A.; Agresti, A.; Bianchi, M.E. Monocytic cells hyperacetylate chromatin protein HMGB1 to redirect it towards secretion. EMBO J. 2003, 22, 5551-5560. [CrossRef]

71. Sekiguchi, F.; Domoto, R.; Nakashima, K.; Yamasoba, D.; Yamanishi, H.; Tsubota, M.; Wake, H.; Nishibori, M.; Kawabata, A. Paclitaxel-induced HMGB1 release from macrophages and its implication for peripheral neuropathy in mice: Evidence for a neuroimmune crosstalk. Neuropharmacology 2018, 141, 201-213. [CrossRef] [PubMed]

72. Yang, Z.Y.; Li, L.; Chen, L.J.; Yuan, W.W.; Dong, L.M.; Zhang, Y.S.; Wu, H.S.; Wang, C.Y. PARP-1 Mediates LPS-Induced HMGB1 Release by Macrophages through Regulation of HMGB1 Acetylation. J. Immunol. 2014, 193, 6114-6123. [CrossRef] [PubMed]

73. Wang, D.; Liu, K.; Fukuyasu, Y.; Teshigawara, K.; Fu, L.; Wake, H.; Ohtsuka, A.; Nishibori, M. HMGB1 Translocation in Neurons after Ischemic Insult: Subcellular Localization in Mitochondria and Peroxisomes. Cells 2020, 9, 643. [CrossRef] [PubMed]

74. Zhang, F.F.; Morioka, N.; Harano, S.; Nakamura, Y.; Liu, K.; Nishibori, M.; Hisaoka-Nakashima, K.; Nakata, Y. Perineural expression of high-mobility group box-1 contributes to long-lasting mechanical hypersensitivity via matrix metalloprotease-9 up-regulation in mice with painful peripheral neuropathy. J. Neurochem. 2016, 136, 837-850. [CrossRef] [PubMed] 
75. Alaraj, A.; Charbel, F.T.; Amin-Hanjani, S. Peri-operative measures for treatment and prevention of cerebral vasospasm following subarachnoid hemorrhage. Neurol. Res. 2009, 31, 651-659. [CrossRef]

76. Kassell, N.F.; Sasaki, T.; Colohan, A.R.; Nazar, G. Cerebral vasospasm following aneurysmal subarachnoid hemorrhage. Stroke A J. Cereb. Circ. 1985, 16, 562-572. [CrossRef]

77. Eisenhut, M. Vasospasm in cerebral inflammation. Int. J. Inflam. 2014, 2014, 509707. [CrossRef]

78. Nakamura, K.; Nishimura, J.; Hirano, K.; Ibayashi, S.; Fujishima, M.; Kanaide, H. Hydroxyfasudil, an active metabolite of fasudil hydrochloride, relaxes the rabbit basilar artery by disinhibition of myosin light chain phosphatase. J. Cereb. Blood Flow Metab. J. Int. Soc. Cereb. Blood Flow Metab. 2001, 21, 876-885. [CrossRef]

79. Pradilla, G.; Chaichana, K.L.; Hoang, S.; Huang, J.; Tamargo, R.J. Inflammation and cerebral vasospasm after subarachnoid hemorrhage. Neurosurg. Clin. N. Am. 2010, 21, 365-379. [CrossRef]

80. Manoel, A.L.D.; Macdonald, R.L. Neuroinflammation as a Target for Intervention in Subarachnoid Hemorrhage. Front. Neurol. 2018, 9. [CrossRef]

81. Macdonald, R.L. Delayed neurological deterioration after subarachnoid haemorrhage. Nat. Rev. Neurol. 2014, 10, 44-58. [CrossRef] [PubMed]

82. Shen, J.; Pan, J.W.; Fan, Z.X.; Xiong, X.X.; Zhan, R.Y. Dissociation of vasospasm-related morbidity and outcomes in patients with aneurysmal subarachnoid hemorrhage treated with clazosentan: A meta-analysis of randomized controlled trials. J. Neurosurg. 2013, 119, 180-189. [CrossRef] [PubMed]

83. Veldeman, M.; Hollig, A.; Clusmann, H.; Stevanovic, A.; Rossaint, R.; Coburn, M. Delayed cerebral ischaemia prevention and treatment after aneurysmal subarachnoid haemorrhage: A systematic review. Br. J. Anaesth. 2016, 117, 17-40. [CrossRef] [PubMed]

84. Iseda, K.; Ono, S.; Onoda, K.; Satoh, M.; Manabe, H.; Nishiguchi, M.; Takahashi, K.; Tokunaga, K.; Sugiu, K.; Date, I. Antivasospastic and antiinflammatory effects of caspase inhibitor in experimental subarachnoid hemorrhage. J. Neurosurg. 2007, 107, 128-135. [CrossRef] [PubMed]

85. Satoh, M.; Date, I.; Nakajima, M.; Takahashi, K.; Iseda, K.; Tamiya, T.; Ohmoto, T.; Ninomiya, Y.; Asari, S. Inhibition of poly(ADP-ribose) polymerase attenuates cerebral vasospasm after subarachnoid hemorrhage in rabbits. Stroke A J. Cereb. Circ. 2001, 32, 225-231. [CrossRef] [PubMed]

86. Zhou, M.L.; Shi, J.X.; Hang, C.H.; Cheng, H.L.; Qi, X.P.; Mao, L.; Chen, K.F.; Yin, H.X. Potential contribution of nuclear factor-kappaB to cerebral vasospasm after experimental subarachnoid hemorrhage in rabbits. J. Cereb. Blood Flow Metab. J. Int. Soc. Cereb. Blood Flow Metab. 2007, 27, 1583-1592. [CrossRef] [PubMed]

87. Haruma, J.; Teshigawara, K.; Hishikawa, T.; Wang, D.; Liu, K.; Wake, H.; Mori, S.; Takahashi, H.K.; Sugiu, K.; Date, I.; et al. Anti-high mobility group box-1 (HMGB1) antibody attenuates delayed cerebral vasospasm and brain injury after subarachnoid hemorrhage in rats. Sci. Rep. 2016, 6, 37755. [CrossRef]

88. Li, Y.; Sun, F.; Jing, Z.; Wang, X.; Hua, X.; Wan, L. Glycyrrhizic acid exerts anti-inflammatory effect to improve cerebral vasospasm secondary to subarachnoid hemorrhage in a rat model. Neurol. Res. 2017, 39, 727-732. [CrossRef]

89. Kai, Y.; Hirano, K.; Maeda, Y.; Nishimura, J.; Sasaki, T.; Kanaide, H. Prevention of the hypercontractile response to thrombin by proteinase-activated receptor-1 antagonist in subarachnoid hemorrhage. Stroke A J. Cereb. Circ. 2007, 38, 3259-3265. [CrossRef]

90. Maeda, Y.; Hirano, K.; Kai, Y.; Hirano, M.; Suzuki, S.O.; Sasaki, T.; Kanaide, H. Up-regulation of proteinase-activated receptor 1 and increased contractile responses to thrombin after subarachnoid haemorrhage. Br. J. Pharmacol. 2007, 152, 1131-1139. [CrossRef]

91. Zhao, X.D.; Mao, H.Y.; Lv, J.; Lu, X.J. Expression of high-mobility group box-1 (HMGB1) in the basilar artery after experimental subarachnoid hemorrhage. J. Clin. Neurosci. J. Neurosurg. Soc. Australas. 2016, 27, 161-165. [CrossRef] [PubMed]

92. Wang, K.Y.; Yu, G.F.; Zhang, Z.Y.; Huang, Q.; Dong, X.Q. Plasma high-mobility group box 1 levels and prediction of outcome in patients with traumatic brain injury. Clin. Chim. Acta 2012, 413, 1737-1741. [CrossRef] [PubMed]

93. Au, A.K.; Aneja, R.K.; Bell, M.J.; Bayir, H.; Feldman, K.; Adelson, P.D.; Fink, E.L.; Kochanek, P.M.; Clark, R.S. Cerebrospinal fluid levels of high-mobility group box 1 and cytochrome $C$ predict outcome after pediatric traumatic brain injury. J. Neurotrauma 2012, 29, 2013-2021. [CrossRef] [PubMed]

94. Pang, H.; Huang, T.; Song, J.; Li, D.; Zhao, Y.; Ma, X. Inhibiting HMGB1 with Glycyrrhizic Acid Protects Brain Injury after DAI via Its Anti-Inflammatory Effect. Mediat. Inflamm. 2016, 2016, 4569521. [CrossRef] 
95. Su, X.; Wang, H.; Zhao, J.; Pan, H.; Mao, L. Beneficial effects of ethyl pyruvate through inhibiting high-mobility group box 1 expression and TLR4/NF-kappaB pathway after traumatic brain injury in the rat. Mediat. Inflamm. 2011, 2011, 807142. [CrossRef]

96. Webster, K.M.; Shultz, S.R.; Ozturk, E.; Dill, L.K.; Sun, M.; Casillas-Espinosa, P.; Jones, N.C.; Crack, P.J.; O’Brien, T.J.; Semple, B.D. Targeting high-mobility group box protein 1 (HMGB1) in pediatric traumatic brain injury: Chronic neuroinflammatory, behavioral, and epileptogenic consequences. Exp. Neurol. 2019, 320, 112979. [CrossRef]

97. Nakajo, M.; Uezono, N.; Nakashima, H.; Wake, H.; Komiya, S.; Nishibori, M.; Nakashima, K. Therapeutic time window of anti-high mobility group box-1 antibody administration in mouse model of spinal cord injury. Neurosci. Res. 2019, 141, 63-70. [CrossRef]

98. Uezono, N.; Zhu, Y.; Fujimoto, Y.; Yasui, T.; Matsuda, T.; Nakajo, M.; Abematsu, M.; Setoguchi, T.; Mori, S.; Takahashi, H.K.; et al. Prior Treatment with Anti-High Mobility Group Box-1 Antibody Boosts Human Neural Stem Cell Transplantation-Mediated Functional Recovery After Spinal Cord Injury. Stem Cells 2018, 36, 737-750. [CrossRef]

99. Aneja, R.K.; Alcamo, A.M.; Cummings, J.; Vagni, V.; Feldman, K.; Wang, Q.; Dixon, C.E.; Billiar, T.R.; Kochanek, P.M. Lack of Benefit on Brain Edema, Blood-Brain Barrier Permeability, or Cognitive Outcome in Global Inducible High Mobility Group Box 1 Knockout Mice Despite Tissue Sparing after Experimental Traumatic Brain Injury. J. Neurotrauma 2019, 36, 360-369. [CrossRef]

100. Librizzi, L.; Noe, F.; Vezzani, A.; de Curtis, M.; Ravizza, T. Seizure-induced brain-borne inflammation sustains seizure recurrence and blood-brain barrier damage. Ann. Neurol. 2012, 72, 82-90. [CrossRef]

101. Friedman, A.; Kaufer, D.; Heinemann, U. Blood-brain barrier breakdown-inducing astrocytic transformation: Novel targets for the prevention of epilepsy. Epilepsy Res. 2009, 85, 142-149. [CrossRef] [PubMed]

102. Iori, V.; Maroso, M.; Rizzi, M.; Iyer, A.M.; Vertemara, R.; Carli, M.; Agresti, A.; Antonelli, A.; Bianchi, M.E.; Aronica, E.; et al. Receptor for Advanced Glycation Endproducts is upregulated in temporal lobe epilepsy and contributes to experimental seizures. Neurobiol. Dis. 2013, 58, 102-114. [CrossRef] [PubMed]

103. Louboutin, J.P.; Chekmasova, A.; Marusich, E.; Agrawal, L.; Strayer, D.S. Role of CCR5 and its ligands in the control of vascular inflammation and leukocyte recruitment required for acute excitotoxic seizure induction and neural damage. FASEB J. Publ. Fed. Am. Soc. Exp. Biol. 2011, 25, 737-753. [CrossRef] [PubMed]

104. Oby, E.; Janigro, D. The blood-brain barrier and epilepsy. Epilepsia 2006, 47, 1761-1774. [CrossRef]

105. Maroso, M.; Balosso, S.; Ravizza, T.; Liu, J.; Aronica, E.; Iyer, A.M.; Rossetti, C.; Molteni, M.; Casalgrandi, M.; Manfredi, A.A.; et al. Toll-like receptor 4 and high-mobility group box-1 are involved in ictogenesis and can be targeted to reduce seizures. Nat. Med. 2010, 16, 413-419. [CrossRef]

106. Choy, M.; Dube, C.M.; Patterson, K.; Barnes, S.R.; Maras, P.; Blood, A.B.; Hasso, A.N.; Obenaus, A.; Baram, T.Z. A novel, noninvasive, predictive epilepsy biomarker with clinical potential. J. Neurosci. J. Soc. Neurosci. 2014, 34, 8672-8684. [CrossRef]

107. Patterson, K.P.; Brennan, G.P.; Curran, M.; Kinney-Lang, E.; Dube, C.; Rashid, F.; Ly, C.; Obenaus, A.; Baram, T.Z. Rapid, Coordinate Inflammatory Responses after Experimental Febrile Status Epilepticus: Implications for Epileptogenesis. eNeuro 2015, 2. [CrossRef]

108. Zhao, J.; Wang, Y.; Xu, C.; Liu, K.; Wang, Y.; Chen, L.; Wu, X.; Gao, F.; Guo, Y.; Zhu, J.; et al. Therapeutic potential of an anti-high mobility group box-1 monoclonal antibody in epilepsy. Brain Behav. Immun. 2017, 64, 308-319. [CrossRef]

109. Hyun, H.W.; Ko, A.R.; Kang, T.C. Mitochondrial Translocation of High Mobility Group Box 1 Facilitates LIM Kinase 2-Mediated Programmed Necrotic Neuronal Death. Front. Cell. Neurosci. 2016, 10, 99. [CrossRef]

110. Kim, J.E.; Kang, T.C. Differential Roles of Mitochondrial Translocation of Active Caspase-3 and HMGB1 in Neuronal Death Induced by Status Epilepticus. Front. Cell. Neurosci. 2018, 12, 301. [CrossRef]

111. Li, Y.J.; Wang, L.; Zhang, B.; Gao, F.; Yang, C.M. Glycyrrhizin, an HMGB1 inhibitor, exhibits neuroprotective effects in rats after lithium-pilocarpine-induced status epilepticus. J. Pharm. Pharm. 2019, 71, 390-399. [CrossRef] [PubMed]

112. Rosciszewski, G.; Cadena, V.; Auzmendi, J.; Cieri, M.B.; Lukin, J.; Rossi, A.R.; Murta, V.; Villarreal, A.; Reines, A.; Gomes, F.C.A.; et al. Detrimental Effects of HMGB-1 Require Microglial-Astroglial Interaction: Implications for the Status Epilepticus -Induced Neuroinflammation. Front. Cell. Neurosci. 2019, 13, 380. [CrossRef] [PubMed] 
113. Zhao, J.L.; Zheng, Y.; Liu, K.Y.; Chen, J.Z.; Lai, N.X.; Fei, F.; Shi, J.Y.; Xu, C.L.; Wang, S.; Nishibori, M.; et al. HMGB1 Is a Therapeutic Target and Biomarker in Diazepam-Refractory Status Epilepticus with Wide Time Window. Neurotherapeutics 2020, 17, 710-721. [CrossRef] [PubMed]

114. Paudel, Y.N.; Shaikh, M.F.; Chakraborti, A.; Kumari, Y.; Aledo-Serrano, A.; Aleksovska, K.; Alvim, M.K.M.; Othman, I. HMGB1: A Common Biomarker and Potential Target for TBI, Neuroinflammation, Epilepsy, and Cognitive Dysfunction. Front. Neurosci. 2018, 12, 628. [CrossRef]

115. Ravizza, T.; Terrone, G.; Salamone, A.; Frigerio, F.; Balosso, S.; Antoine, D.J.; Vezzani, A. High Mobility Group Box 1 is a novel pathogenic factor and a mechanistic biomarker for epilepsy. Brain Behav. Immun. 2018, 72, 14-21. [CrossRef]

116. Nass, R.D.; Wagner, M.; Surges, R.; Holdenrieder, S. Time courses of HMGB1 and other inflammatory markers after generalized convulsive seizures. Epilepsy Res. 2020, 162, 106301. [CrossRef]

117. Wang, F.; Ji, S.; Wang, M.; Liu, L.; Li, Q.; Jiang, F.; Cen, J.; Ji, B. HMGB1 promoted P-glycoprotein at the blood-brain barrier in MCAO rats via TLR4/NF-kappaB signaling pathway. Eur. J. Pharm. 2020, 880, 173189. [CrossRef]

118. Xie, Y.; Yu, N.; Chen, Y.; Zhang, K.; Ma, H.Y.; Di, Q. HMGB1 regulates P-glycoprotein expression in status epilepticus rat brains via the RAGE/NF-kappaB signaling pathway. Mol. Med. Rep. 2017, 16, 1691-1700. [CrossRef]

119. Kisler, K.; Nelson, A.R.; Montagne, A.; Zlokovic, B.V. Cerebral blood flow regulation and neurovascular dysfunction in Alzheimer disease. Nat. Rev. Neurosci. 2017, 18, 419-434. [CrossRef]

120. Sweeney, M.D.; Sagare, A.P.; Zlokovic, B.V. Blood-brain barrier breakdown in Alzheimer disease and other neurodegenerative disorders. Nat. Rev. Neurol. 2018, 14, 133-150. [CrossRef]

121. Di Marco, L.Y.; Venneri, A.; Farkas, E.; Evans, P.C.; Marzo, A.; Frangi, A.F. Vascular dysfunction in the pathogenesis of Alzheimer's disease-A review of endothelium-mediated mechanisms and ensuing vicious circles. Neurobiol. Dis. 2015, 82, 593-606. [CrossRef] [PubMed]

122. Festoff, B.W.; Sajja, R.K.; van Dreden, P.; Cucullo, L. HMGB1 and thrombin mediate the blood-brain barrier dysfunction acting as biomarkers of neuroinflammation and progression to neurodegeneration in Alzheimer's disease. J. Neuroinflamm. 2016, 13. [CrossRef] [PubMed]

123. Zenaro, E.; Piacentino, G.; Constantin, G. The blood-brain barrier in Alzheimer's disease. Neurobiol. Dis. 2017, 107, 41-56. [CrossRef] [PubMed]

124. McAleese, K.E.; Graham, S.; Dey, M.; Walker, L.; Erskine, D.; Johnson, M.; Johnston, E.; Thomas, A.J.; McKeith, I.G.; DeCarli, C.; et al. Extravascular fibrinogen in the white matter of Alzheimer's disease and normal aged brains: Implications for fibrinogen as a biomarker for Alzheimer's disease. Brain Pathol. 2019, 29, 414-424. [CrossRef] [PubMed]

125. Zipser, B.D.; Johanson, C.E.; Gonzalez, L.; Berzin, T.M.; Tavares, R.; Hulette, C.M.; Vitek, M.P.; Hovanesian, V.; Stopa, E.G. Microvascular injury and blood-brain barrier leakage in Alzheimer's disease. Neurobiol. Aging 2007, 28, 977-986. [CrossRef] [PubMed]

126. Kook, S.Y.; Hong, H.S.; Moon, M.; Ha, C.M.; Chang, S.; Mook-Jung, I. Abeta(1)(-)(4)(2)-RAGE interaction disrupts tight junctions of the blood-brain barrier via $\mathrm{Ca}(2)(+)$-calcineurin signaling. J. Neurosci. J. Soc. Neurosci. 2012, 32, 8845-8854. [CrossRef]

127. Wan, W.; Cao, L.; Liu, L.; Zhang, C.; Kalionis, B.; Tai, X.; Li, Y.; Xia, S. Abeta(1-42) oligomer-induced leakage in an in vitro blood-brain barrier model is associated with up-regulation of RAGE and metalloproteinases, and down-regulation of tight junction scaffold proteins. J. Neurochem. 2015, 134, 382-393. [CrossRef]

128. Montagne, A.; Zhao, Z.; Zlokovic, B.V. Alzheimer's disease: A matter of blood-brain barrier dysfunction? J. Exp. Med. 2017, 214, 3151-3169. [CrossRef]

129. Origlia, N.; Righi, M.; Capsoni, S.; Cattaneo, A.; Fang, F.; Stern, D.M.; Chen, J.X.; Schmidt, A.M.; Arancio, O.; Yan, S.D.; et al. Receptor for advanced glycation end product-dependent activation of p38 mitogen-activated protein kinase contributes to amyloid-beta-mediated cortical synaptic dysfunction. J. Neurosci. J. Soc. Neurosci. 2008, 28, 3521-3530. [CrossRef]

130. Zhang, H.; Wang, Y.; Yan, S.; Du, F.; Wu, L.; Yan, S.; Yan, S.S. Genetic deficiency of neuronal RAGE protects against AGE-induced synaptic injury. Cell Death Dis. 2014, 5, e1288. [CrossRef]

131. Fujita, K.; Motoki, K.; Tagawa, K.; Chen, X.G.; Hama, H.; Nakajima, K.; Homma, H.; Tamura, T.; Watanabe, H.; Katsuno, M.; et al. HMGB1, a pathogenic molecule that induces neurite degeneration via TLR4-MARCKS, is a potential therapeutic target for Alzheimer's disease. Sci. Rep. 2016, 6. [CrossRef] [PubMed] 
132. Okazawa, H. Ultra-Early Phase pathologies of Alzheimer's disease and other neurodegenerative diseases. Proc. Jpn. Acad. Ser. B Phys. Biol. Sci. 2017, 93, 361-377. [CrossRef]

133. Santoro, M.; Maetzler, W.; Stathakos, P.; Martin, H.L.; Hobert, M.A.; Rattay, T.W.; Gasser, T.; Forrester, J.V.; Berg, D.; Tracey, K.J.; et al. In-vivo evidence that high mobility group box 1 exerts deleterious effects in the 1-methyl-4-phenyl-1,2,3,6-tetrahydropyridine model and Parkinson's disease which can be attenuated by glycyrrhizin. Neurobiol. Dis. 2016, 91,59-68. [CrossRef] [PubMed]

134. Guan, Y.; Li, Y.; Zhao, G.; Li, Y. HMGB1 promotes the starvation-induced autophagic degradation of alpha-synuclein in SH-SY5Y cells Atg 5-dependently. Life Sci. 2018, 202, 1-10. [CrossRef] [PubMed]

135. Wang, K.; Huang, J.; Xie, W.; Huang, L.; Zhong, C.; Chen, Z. Beclin1 and HMGB1 ameliorate the alpha-synuclein-mediated autophagy inhibition in PC12 cells. Diagn. Pathol. 2016, 11, 15. [CrossRef]

136. Andersson, A.; Covacu, R.; Sunnemark, D.; Danilov, A.I.; Dal Bianco, A.; Khademi, M.; Wallstrom, E.; Lobell, A.; Brundin, L.; Lassmann, H.; et al. Pivotal advance: HMGB1 expression in active lesions of human and experimental multiple sclerosis. J. Leukoc. Biol. 2008, 84, 1248-1255. [CrossRef]

137. Robinson, A.P.; Caldis, M.W.; Harp, C.T.; Goings, G.E.; Miller, S.D. High-mobility group box 1 protein (HMGB1) neutralization ameliorates experimental autoimmune encephalomyelitis. J. Autoimmun. 2013, 43, 32-43. [CrossRef]

138. Sun, Y.; Chen, H.; Dai, J.; Wan, Z.; Xiong, P.; Xu, Y.; Han, Z.; Chai, W.; Gong, F.; Zheng, F. Glycyrrhizin Protects Mice Against Experimental Autoimmune Encephalomyelitis by Inhibiting High-Mobility Group Box 1 (HMGB1) Expression and Neuronal HMGB1 Release. Front. Immunol. 2018, 9, 1518. [CrossRef]

139. Uzawa, A.; Mori, M.; Taniguchi, J.; Masuda, S.; Muto, M.; Kuwabara, S. Anti-high mobility group box 1 monoclonal antibody ameliorates experimental autoimmune encephalomyelitis. Clin. Exp. Immunol. 2013, 172, 37-43. [CrossRef]

140. Wang, K.C.; Tsai, C.P.; Lee, C.L.; Chen, S.Y.; Chin, L.T.; Chen, S.J. Elevated Plasma High-Mobility Group Box 1 Protein Is a Potential Marker for Neuromyelitis Optica. Neuroscience 2012, 226, 510-516. [CrossRef]

141. Hammen, C. Risk Factors for Depression: An Autobiographical Review. Annu. Rev. Clin. Psychol. 2018, 14, 1-28. [CrossRef] [PubMed]

142. Franklin, T.C.; Xu, C.; Duman, R.S. Depression and sterile inflammation: Essential role of danger associated molecular patterns. Brain Behav. Immun. 2018, 72, 2-13. [CrossRef] [PubMed]

143. Cheng, Y.; Pardo, M.; de Souza Armini, R.; Martinez, A.; Mouhsine, H.; Zagury, J.-F.; Jope, R.S.; Beurel, E. Stress-induced neuroinflammation is mediated by GSK3-dependent TLR4 signaling that promotes susceptibility to depression-like behavior. Brain Behav. Immun. 2016, 53, 207-222. [CrossRef] [PubMed]

144. Lian, Y.-J.; Gong, H.; Wu, T.-Y.; Su, W.-J.; Zhang, Y.; Yang, Y.-Y.; Peng, W.; Zhang, T.; Zhou, J.-R.; Jiang, C.-L. Ds-HMGB1 and fr-HMGB induce depressive behavior through neuroinflammation in contrast to nonoxid-HMGB1. Brain Behav. Immun. 2017, 59, 322-332. [CrossRef]

145. Franklin, T.C.; Wohleb, E.S.; Zhang, Y.; Fogaca, M.; Hare, B.; Duman, R.S. Persistent Increase in Microglial RAGE Contributes to Chronic Stress-Induced Priming of Depressive-like Behavior. Biol. Psychiatry 2018, 83, 50-60. [CrossRef] [PubMed]

146. Hisaoka-Nakashima, K.; Tomimura, Y.; Yoshii, T.; Ohata, K.; Takada, N.; Zhang, F.F.; Nakamura, Y.; Liu, K.; Wake, H.; Nishibori, M.; et al. High-mobility group box 1-mediated microglial activation induces anxiodepressive-like behaviors in mice with neuropathic pain. Prog. Neuropsychopharmacol. Biol. Psychiatry 2019, 92, 347-362. [CrossRef]

147. Wake, H.; Mori, S.; Liu, K.; Morioka, Y.; Teshigawara, K.; Sakaguchi, M.; Kuroda, K.; Gao, Y.; Takahashi, H.; Ohtsuka, A.; et al. Histidine-Rich Glycoprotein Prevents Septic Lethality through Regulation of Immunothrombosis and Inflammation. EBioMedicine 2016, 9, 180-194. [CrossRef]

148. Badve, M.S.; Zhou, Z.; van de Beek, D.; Anderson, C.S.; Hackett, M.L. Frequency of post-stroke pneumonia: Systematic review and meta-analysis of observational studies. Int. J. Stroke 2019, 14, 125-136. [CrossRef]

149. Ge, Y.Q.; Wang, Q.H.; Wang, L.; Wu, H.H.; Peng, C.; Wang, J.J.; Xu, Y.; Xiong, G.; Zhang, Y.Y.; Yi, Y.P. Predicting post-stroke pneumonia using deep neural network approaches. Int. J. Med Inform. 2019, 132. [CrossRef]

150. Stanley, D.; Mason, L.J.; Mackin, K.E.; Srikhanta, Y.N.; Lyras, D.; Prakash, M.D.; Nurgali, K.; Venegas, A.; Hill, M.D.; Moore, R.J.; et al. Translocation and dissemination of commensal bacteria in post-stroke infection. Nat. Med. 2016, 22, 1277-1284. [CrossRef] 
151. Banks, W.A.; Gray, A.M.; Erickson, M.A.; Salameh, T.S.; Damodarasamy, M.; Sheibani, N.; Meabon, J.S.; Wing, E.E.; Morofuji, Y.; Cook, D.G.; et al. Lipopolysaccharide-induced blood-brain barrier disruption: Roles of cyclooxygenase, oxidative stress, neuroinflammation, and elements of the neurovascular unit. $J$. Neuroinflamm. 2015, 12, 223. [CrossRef] [PubMed]

152. Cheng, X.; Yang, Y.L.; Yang, H.; Wang, Y.H.; Du, G.H. Kaempferol alleviates LPS-induced neuroinflammation and BBB dysfunction in mice via inhibiting HMGB1 release and down-regulating TLR4/MyD88 pathway. Int. Immunopharmacol. 2018, 56, 29-35. [CrossRef] [PubMed]

153. Kim, I.D.; Lee, H.; Kim, S.W.; Lee, H.K.; Choi, J.; Han, P.L.; Lee, J.K. Alarmin HMGB1 induces systemic and brain inflammatory exacerbation in post-stroke infection rat model. Cell Death Dis. 2018, 9, 426. [CrossRef] [PubMed]

154. Forsberg, A.; Cervenka, S.; Jonsson Fagerlund, M.; Rasmussen, L.S.; Zetterberg, H.; Erlandsson Harris, H.; Stridh, P.; Christensson, E.; Granstrom, A.; Schening, A.; et al. The immune response of the human brain to abdominal surgery. Ann. Neurol. 2017, 81, 572-582. [CrossRef]

155. Terrando, N.; Eriksson, L.I.; Ryu, J.K.; Yang, T.; Monaco, C.; Feldmann, M.; Jonsson Fagerlund, M.; Charo, I.F.; Akassoglou, K.; Maze, M. Resolving postoperative neuroinflammation and cognitive decline. Ann. Neurol. 2011, 70, 986-995. [CrossRef] [PubMed]

156. Nosaka, N.; Hatayama, K.; Yamada, M.; Fujii, Y.; Yashiro, M.; Wake, H.; Tsukahara, H.; Nishibori, M.; Morishima, T. Anti-high mobility group box-1 monoclonal antibody treatment of brain edema induced by influenza infection and lipopolysaccharide. J. Med. Virol. 2018, 90, 1192-1198. [CrossRef]

157. Varatharaj, A.; Galea, I. The blood-brain barrier in systemic inflammation. Brain Behav. Immun. 2017, 60, 1-12. [CrossRef]

158. Helms, J.; Kremer, S.; Merdji, H.; Schenck, M.; Severac, F.; Clere-Jehl, R.; Studer, A.; Radosavljevic, M.; Kummerlen, C.; Monnier, A.; et al. Delirium and encephalopathy in severe COVID-19: A cohort analysis of ICU patients. Crit. Care 2020, 24, 491. [CrossRef]

159. Chen, L.T.; Long, X.L.; Xu, Q.; Tan, J.Q.; Wang, G.X.; Cao, Y.; Wei, J.; Luo, H.; Zhu, H.; Huang, L.; et al. Elevated serum levels of S100A8/A9 and HMGB1 at hospital admission are correlated with inferior clinical outcomes in COVID-19 patients. Cell. Mol. Immunol. 2020, 17, 992-994. [CrossRef]

160. Rodrigues, S.F.; Granger, D.N. Blood cells and endothelial barrier function. Tissue Barriers 2015, 3, e978720. [CrossRef]

161. Hohne, C.; Wenzel, M.; Angele, B.; Hammerschmidt, S.; Hacker, H.; Klein, M.; Bierhaus, A.; Sperandio, M.; Pfister, H.W.; Koedel, U. High mobility group box 1 prolongs inflammation and worsens disease in pneumococcal meningitis. Brain 2013, 136, 1746-1759. [CrossRef] [PubMed]

162. Yang, L.; Wang, F.; Yang, L.; Yuan, Y.; Chen, Y.; Zhang, G.; Fan, Z. HMGB1 a-Box Reverses Brain Edema and Deterioration of Neurological Function in a Traumatic Brain Injury Mouse Model. Cell. Physiol. Biochem. 2018, 46, 2532-2542. [CrossRef]

163. Kim, I.D.; Shin, J.H.; Kim, S.W.; Choi, S.; Ahn, J.; Han, P.L.; Park, J.S.; Lee, J.K. Intranasal delivery of HMGB1 siRNA confers target gene knockdown and robust neuroprotection in the postischemic brain. Mol. Ther. 2012, 20, 829-839. [CrossRef] [PubMed]

164. Kim, I.D.; Shin, J.H.; Lee, H.K.; Jin, Y.C.; Lee, J.K. Intranasal delivery of HMGB1-binding heptamer peptide confers a robust neuroprotection in the postischemic brain. Neurosci. Lett. 2012, 525, 179-183. [CrossRef]

165. Yu, Y.M.; Kim, J.B.; Lee, K.W.; Kim, S.Y.; Han, P.L.; Lee, J.K. Inhibition of the cerebral ischemic injury by ethyl pyruvate with a wide therapeutic window. Stroke A J. Cereb. Circ. 2005, 36, 2238-2243. [CrossRef] [PubMed]

166. Wang, Q.; Ding, Q.; Zhou, Y.M.; Gou, X.C.; Hou, L.C.; Chen, S.Y.; Zhu, Z.H.; Xiong, L.Z. Ethyl Pyruvate Attenuates Spinal Cord Ischemic Injury with a Wide Therapeutic Window through Inhibiting High-mobility Group Box 1 Release in Rabbits. Anesthesiology 2009, 110, 1279-1286. [CrossRef]

167. Kim, S.W.; Jin, Y.; Shin, J.H.; Kim, I.D.; Lee, H.K.; Park, S.; Han, P.L.; Lee, J.K. Glycyrrhizic acid affords robust neuroprotection in the postischemic brain via anti-inflammatory effect by inhibiting HMGB1 phosphorylation and secretion. Neurobiol. Dis. 2012, 46, 147-156. [CrossRef]

168. Ni, B.; Cao, Z.; Liu, Y. Glycyrrhizin protects spinal cord and reduces inflammation in spinal cord ischemia-reperfusion injury. Int. J. Neurosci. 2013, 123, 745-751. [CrossRef]

169. Gong, G.; Yuan, L.B.; Hu, L.; Wu, W.; Yin, L.; Hou, J.L.; Liu, Y.H.; Zhou, L.S. Glycyrrhizin attenuates rat ischemic spinal cord injury by suppressing inflammatory cytokines and HMGB1. Acta Pharm. Sin. 2012, 33, 11-18. [CrossRef] 
170. Ohnishi, M.; Katsuki, H.; Fukutomi, C.; Takahashi, M.; Motomura, M.; Fukunaga, M.; Matsuoka, Y.; Isohama, Y.; Izumi, Y.; Kume, T.; et al. HMGB1 inhibitor glycyrrhizin attenuates intracerebral hemorrhage-induced injury in rats. Neuropharmacology 2011, 61, 975-980. [CrossRef]

171. Wang, L.; Zhang, X.; Liu, L.; Cui, L.; Yang, R.; Li, M.; Du, W. Tanshinone II A down-regulates HMGB1, RAGE, TLR4, NF-kappaB expression, ameliorates BBB permeability and endothelial cell function, and protects rat brains against focal ischemia. Brain Res. 2010, 1321, 143-151. [CrossRef] [PubMed]

172. Zhu, J.R.; Lu, H.D.; Guo, C.; Fang, W.R.; Zhao, H.D.; Zhou, J.S.; Wang, F.; Zhao, Y.L.; Li, Y.M.; Zhang, Y.D.; et al. Berberine attenuates ischemia-reperfusion injury through inhibiting HMGB1 release and NF-kappaB nuclear translocation. Acta Pharm. Sin. 2018, 39, 1706-1715. [CrossRef] [PubMed]

173. Xie, W.; Zhu, T.; Dong, X.; Nan, F.; Meng, X.; Zhou, P.; Sun, G.; Sun, X. HMGB1-triggered inflammation inhibition of notoginseng leaf triterpenes against cerebral ischemia and reperfusion injury via MAPK and NF-kappaB signaling pathways. Biomolecules 2019, 9, 512. [CrossRef] [PubMed]

174. Wang, Y.; Li, L.; Deng, S.; Liu, F.; He, Z. Ursolic Acid Ameliorates Inflammation in Cerebral Ischemia and Reperfusion Injury Possibly via High Mobility Group Box 1/Toll-Like Receptor 4/NFkappaB Pathway. Front. Neurol. 2018, 9, 253. [CrossRef]

175. Chen, X.; Wu, S.; Chen, C.; Xie, B.; Fang, Z.; Hu, W.; Chen, J.; Fu, H.; He, H. Omega-3 polyunsaturated fatty acid supplementation attenuates microglial-induced inflammation by inhibiting the HMGB1/TLR4/NF-kappaB pathway following experimental traumatic brain injury. J. Neuroinflamm. 2017, 14, 143. [CrossRef]

176. Nakamura, Y.; Nakano, T.; Irie, K.; Sano, K.; Tanaka, J.; Yamashita, Y.; Satho, T.; Matsuo, K.; Fujioka, M.; Ishikura, H.; et al. Recombinant human soluble thrombomodulin ameliorates cerebral ischemic injury through a high-mobility group box 1 inhibitory mechanism without hemorrhagic complications in mice. $J$. Neurol. Sci. 2016, 362, 278-282. [CrossRef]

Publisher's Note: MDPI stays neutral with regard to jurisdictional claims in published maps and institutional affiliations. 